\title{
DIGITALCOMMONS
}

@WAYNESTATE-

Wayne State University

$1-1-2005$

\section{Is Hindsight 20-20? Reconsidering the Importance of Pre-Constitutional Documents}

\author{
Kirsten Matoy Carlson \\ University of Michigan, kirsten.carlson@wayne.edu
}

\section{Recommended Citation}

Kirsten Matoy Carlson, Is Hindsight 20-20? Reconsidering the Importance of Pre-Constitutional Documents, 30 Am. Indian L. Rev. 1 (2005).

Available at: https://digitalcommons.wayne.edu/lawfrp/123

This Article is brought to you for free and open access by the Law School at DigitalCommons@WayneState. It has been accepted for inclusion in Law Faculty Research Publications by an authorized administrator of DigitalCommons@WayneState. 


\title{
IS HINDSIGHT 20-20? RECONSIDERING THE IMPORTANCE OF PRE-CONSTITUTIONAL DOCUMENTS
}

\author{
Kirsten Matoy Carlson*
}

Many constitutional orders, including the United States, have yet to determine the legal and political status of pre-constitutional documents written prior to the enactment of a final constitution. This article argues that preconstitutional documents should be critically analyzed by their respective constitutional communities. It maintains that pre-constitutional documents play a key role in constitutional orders by identifying conflicts that remain over time and contends that critical analysis of these documents facilitates deeper understandings of constitutional politics. It demonstrates how preconstitutional documents can be used as diagnostic tools for identifying and better understanding persistent constitutional tensions through a case study of a Peruvian pre-constitutional document. The case study indicates that even underappreciated pre-constitutional documents can broaden understandings of contemporary constitutional politics. The article concludes that preconstitutional documents play a role in current constitutionalism and that legal communities should consider them more seriously.

\section{Introduction}

Shooting off bottle rockets, marching in ticker tape parades, waving the stars and stripes, and watching spectacular red, white, and blue fireworks explode in the dark sky, every small town, big city, remote village and cattle crossing stops momentarily in midsummer to celebrate the anniversary of the signing of the Declaration of Independence. ${ }^{1}$ Yet we do not pause for a second thought

1. Ph.D. candidate, Department of Political Science, University of Michigan. B.A., Johns Hopkins University (1997); M.A., Victoria University of Wellington, New Zealand (Fulbright Scholar) (1999); J.D., University of Michigan (2003). My research was supported by a Clara Belfield and Henry Bates Overseas Fellowship from the Center for International and Comparative Law at the University of Michigan Law School. I extend special thanks to Milner Ball, Sarah Chambers, Matthew Fletcher, Cameron Fraser, Elizabeth Kronk, Carlton F.W. Larson, Craig Lawler, Joan Sitomer, Mark Tushnet, Monika Tutschka, John Ursu, and James Boyd White for reading earlier drafts of this article.

1. Americans have celebrated July 4th since 1777 . For a brief history of early Fourth of July festivities, see Carlton F.W. Larson, The Declaration of Independence: A 225th Anniversary Re-Interpretation, 76 WASH. L. REV. 701, 750-51 (2001). 
on the anniversary of the signing or ratification of our Constitution, ${ }^{2}$ and while we call Columbus Day a federal holiday, no one celebrates it. Rather we identify our founding and project all of our patriotism and our love of country and Constitution onto the festivities of the Fourth of July.

The focal point for our story of origin is not the Constitution or the discovery of the New World by Europeans but the Declaration of Independence. ${ }^{3}$ We identify our origin with a moment in between discovery and the formation of our constitutional government and hail it as both the origin of our presence here and our Constitution. Our constitutional story thus begins before the drafting of our Constitution with an earlier pre-constitutional document, which we recognize every July 4th as not just a declaration of independence, but as a symbol of the beginning of the constitutional democracy that many proudly assert to be the best in the world.

Despite our July Fourth festivities and the widespread public attention given to the Declaration of Independence, its place within our constitutional system continues to be widely debated. ${ }^{4}$ While it is often invoked rhetorically, the Declaration of Independence is not universally accepted as a binding legal document and its precedential value within our constitutional system remains uncertain. ${ }^{5}$

The obscure place of the Declaration of Independence within U.S. constitutionalism is not unique. Texts written prior to formal constitutional creation, or pre-constitutional documents, exist in many states and, like the Declaration of Independence, encapsulate the values underlying the constitutional system. ${ }^{6}$ Some of them, like the Declaration of Independence, the British Magna Carta, and the French Declaration of the Rights of Man and the Citizen, have grabbed the political community's imagination and have tremendous rhetorical value in terms of constitutional politics and debates. ${ }^{7}$

2. Id. at 750 .

3. Ironically, the discovery of the "New World" hints at one of our longest, lingering constitutional questions, namely the constitutional status of American Indians and Indian tribes. See generally VINE DELORIA, JR. \& DAVID E. WILKINS, TRIBES, TREATIES, AND CONSTITUTIONAL TRIBULATIONS (1999); Milner S. Ball, Stories of Origin and Constitutional Possibilities, 87 MICH. L. REV. 2280, 2280 (1989) (detailing how American Indians remain outside of and problematic for the United States' constitutional narrative).

4. Larson, supra note 1, at 701-02; see also MARK TUSHNET, TAKING THE CONSTITUTION AWAY FROM THE COURTS (1999).

5. Larson, supra note 1, at 701-02.

6. Introduction to CONSTITUTIONS IN DEMOCRATIC Politics 7 (Vernon Bogdanor ed., 1988). [hereinafter Bogdanor].

7. Id. 
Others have not been remembered so gloriously, if at all. New Zealand's Treaty of Waitangi, for instance, was declared a legal nullity and spent several decades buried in the basement of a rotting government building before being revived as an important foundational text. ${ }^{8}$ Still others remain buried in constitutional history and rarely mentioned in contemporary constitutional dialogues. While these pre-constitutional documents vary in rhetorical use and value, their place within contemporary constitutional politics and law remains largely unknown.

At the same time, the last two decades have witnessed a worldwide surge in constitutionalism, including the creation of new pre-constitutional and constitutional documents. States in Latin America, Eastern Europe, Africa, and most recently, the Middle East, have re-invented their governing structures and political communities through the revision of old or the creation of new constitutions. ${ }^{9}$ As constitutionalism spreads around the globe, more and more pre-constitutional documents are drafted as precursors to final constitutions. The post constitution-making status of pre-constitutional documents is rarely addressed by the new constitutional order. Whether pre-constitutional documents are popularly exalted, rarely remembered, or were written yesterday, their status within constitutional politics and law is often unclear.

The surge in constitutionalism has lead to a similar increase in comparative constitutional scholarship. ${ }^{10}$ Legal scholars and political scientists have demonstrated a renewed academic interest in the study of constitutionalism. Scholars have analyzed the constitution-making processes in South Africa,

8. Waitangi: MaORI and Pakeha Perspectives of the Treaty of Waitangi $x$ (I.H. Kawharu ed., 1989).

9. See, e.g., Cletus Gregor Barié, Pueblos Indígenas y Derechos CONSTITUCIONALES EN AMERICA LaTINA: Un PANORAMA 474 (2000); DONNA LeE VAN COTT, THE FRIENDLY LIQUIDATION OF THE PAST: THE POLITICS OF DIVERSITY IN LATIN AMERICA (2000); Herman Schwartz, THE Struggle for Constitutional Justice IN POSTCOMMUNIST EUROPE (2000); RICHARD SPITZ \& MATTHEW ChASKALSON, THE POLITICS OF TRANSITION: A HIDDEN HISTORY OF SOUTH AFRICA's NEGOTIATED SETTLEMENT (2000).

10. See, e.g., BARIÉ, supra note 9, at 474; VAN COTT, supra note 9; SCHWARTZ, supra note 9; SPITZ \& ChASKALSON, supra note 9; ALEC STONE SWEET, GOVERNING WITH JUDGES: Constitutional Politics IN Europe (2000); Heinz Klug, Participating in Design: Constitution-Making in South Africa, 3 REV. CONST. STUDIES 1 (1996); GARY JEFFREY JACOBSOHN, APPLE OF GOLD: CONSTITUTIONALISM IN ISRAEL AND THE UNITED STATES (1993). 
Europe, and Latin America, ${ }^{11}$ studied the increased development of constitutional courts, ${ }^{12}$ and engaged in cross-constitutional comparisons. ${ }^{13}$

The existence of so many constitutions developing out of written preconstitutional norms, and the renewed interest in the serious study of constitutional politics, makes this an opportune moment to address the question of the place that pre-constitutional documents should have in modern constitutional orders. Should pre-constitutional documents be largely forgotten and discarded, or do they retain some inherent value that suggests that they deserve the attention that at least some of them have received publicly? Is it enough to acknowledge that these documents exist and use them rhetorically? Do they provide key insights into constitutional law and politics that mandate more critical retrospective analysis? What status should we accord these texts today?

Although these questions remain unanswered, some scholars have noted the importance of pre-constitutional documents and a few have even been using pre-constitutional documents to understand contemporary constitutional orders better. ${ }^{14}$ United States constitutional law scholars, such as Jack Balkin, Milner Ball, Carlton Larson, and Mark Tushnet have argued extensively for taking the Declaration of Independence more seriously. ${ }^{15}$ Jack Balkin argues that U.S. constitutionalism can only be understood in light of the Declaration of Independence, which creates the equality narrative central to U.S. constitutional aspirations. ${ }^{16}$ Milner Ball also perceives the Declaration of Independence as key to constitutional equality in the U.S. He traces the extension of equality to groups not originally included in either the Declaration or the Constitution, and then asserts that the ideals of the Declaration remain problematic for American Indians. ${ }^{17}$ While he agrees that the Declaration deserves more legal recognition as a foundational American document, Carlton Larson disputes Balkin and Ball's identification of equality as the central message in the Declaration and

11. See, e.g., VAN COTT, supra note 9; SCHWARTZ, supra note 9; SPITZ \& CHASKALSON, supra note 9.

12. See, e.g., SCHWARTZ, supra note 9; STONE SWEET, supra note 10.

13. See, e.g., VAN COTT, supra note 9; JACOBSOHN, supra note 10.

14. To some extent, even emerging constitutional democracies have found preconstitutional documents as useful in the creation of final constitutions. South African constitution-makers, for example, used their Interim Constitution as a diagnostic tool to identify problems that would need to be resolved in the final constitution.

15. J.M. Balkin, The Declaration and the Promise of a Democratic Culture, 4 WIDENER L. SYMP. J. 167 (1999); TUSHNET, supra note 4; Ball, supra note 3; Larson, supra note 1.

16. Balkin, supra note 15 , at 167 .

17. Ball, supra note 3, at 2296. 
asserts that its deepest principles are about the right of American people to selfgovernment. ${ }^{18}$ Finally, Mark Tushnet contends that the Declaration of Independence and the Preamble to the Constitution form the "thin constitution," which should guide our constitutional dialogue because it emphasizes the values underlying our constitutional system and creates us as a people. ${ }^{19}$ While these scholars present varying views of the Declaration of Independence, they all suggest that it plays an important role in U.S. constitutionalism. ${ }^{20}$

Scholars of U.S. law are not the only ones to observe the relevance of preconstitutional documents to contemporary constitutional politics. In his study of comparative constitutional politics, Gary Jacobsohn uses the U.S. Declaration of Independence and the Israeli Declaration of Independence as departure points to discuss the contemporary theory and practice of constitutionalism in the United States and Israel. ${ }^{21} \mathrm{He}$ argues that these documents are key to understanding contemporary constitutionalism because they "affix a particular political-moral character to their respective polities."22 Canadian legal scholar, John Borrows, identifies another pre-constitutional document, the Royal Proclamation of 1763 as a "fundamental document" that remains constitutionally relevant today. ${ }^{23} \mathrm{He}$ argues that the Royal Proclamation is the basis of the constitutional relationship between Aboriginal

18. Lawson, supra note 1 , at 783.

19. TUSHNET, supra note 4, at 11-12.

20. Debates have also developed over how and when to use other pre-constitutional documents, especially in interpreting the U.S. Constitution. Vasan Kesavan and Michael Stokes Paulsen discuss the debate over the legal use of documents created during the secret drafting of the Constitution. Vasan Kesavan \& Michael Stokes Paulsen, The Interpretive Force of the Constitution's Secret Drafting, 91 GEO. L.J. 1113, 1113-14 (2003). Similarly, scholars have debated how to treat other documents related to the Constitutional Convention. See, e.g., Seth Barrett Tillman, A Textualist Defense of Article I, Section 7, Clause 3: Why Hollingsworth v. Virginia Was Rightly Decided, and Why INS v. Chadha Was Wrongly Reasoned, 83 TEX. L. REV. 1265, 1311-15 (2005); Vasan Kesavan, When Did the Articles of Confederation Cease to Be Law?, 78 Notre DAME L. REV. 35 (2002); Gary Lawson \& Guy Seidman, The First "Establishment" Clause: Article VII and the Post Constitutional Confederation, 78 NOTRE DAME L. REV. 83, 85 (2002). Unlike these scholars, I am not entering into the debates over the role that various documents may play in the originalist method of interpreting the U.S. Constitution. I am more interested in what these pre-constitutional documents tell us about the development of constitutional politics than whether we should use them to interpret constitutions.

21. JACOBSOHN, supra note 10 , at 4-5.

22. Id. at 5 .

23. John Borrows, Constitutional Law from a First Nation Perspective: Self-Government and the Royal Proclamation, 28 U. BRIT. COLUM. L. REV. 1, 3 (1994). 
peoples and Canada and should continue to guide that constitutional relationship. ${ }^{24}$ Similarly, New Zealand scholars have noted the reemergence of the Treaty of Waitangi as a constitutional document there. Long forgotten by the New Zealand government, the Treaty of Waitangi remained central to the claims of Maaori, and their continual reassertion of their rights under the Treaty has led to its established place as a foundational document in New Zealand. ${ }^{25}$

While these scholars suggest that particular pre-constitutional documents should be taken more seriously, they have not considered pre-constitutional documents generally. My work in relation to theirs demonstrates the relevance of pre-constitutional documents. I build on and use their work to suggest that pre-constitutional documents are a genre of constitutional documents that exist across several constitutional orders. I maintain that legal, political, and academic communities have often overlooked the relevance of preconstitutional documents to contemporary constitutional politics.

This article invites legal and political communities to think more critically about pre-constitutional documents and their legal and political status within contemporary constitutional orders. I argue that critical analysis of preconstitutional documents in a constitutional order may be central to understanding major constitutional issues in that polity today. Preconstitutional documents often emphasize tensions that were present at constitution-making and that remain unresolved. They can be used as diagnostic tools to identify and to understand these tensions better and may assist constitutional orders in addressing constitutional tensions identified at but not resolved since constitution-making. Consequently, it is important that these pre-constitutional documents receive critical analysis like constitutions and other legal materials. Thus, I develop a framework for determining which preconstitutional documents should be taken seriously within a constitutional order. Finally, I suggest that even some less well known documents may serve as diagnostic tools for identifying longstanding constitutional conflicts.

In Part I, I argue that pre-constitutional documents deserve to be critically analyzed like other constitutional documents because even underappreciated pre-constitutional documents may be used as diagnostic tools to identify and understand more completely longstanding constitutional tensions and provide key insights into contemporary constitutionalism. I suggest that constitutional

24. Id. at 4-5.

25. See, e.g., P.G. McHugh, Tales of Constitutional Origin and Crown Sovereignty in New Zealand, 52 U. TORONTO L.J. 69 (2002); WAITANGI: MAORI AND PAKEHA PERSPECTIVESOF THE TREATY OF WATTANGI (I.H. Kawharu ed., 1989). 
systems can only determine the appropriate legal status of these documents after they have seriously considered their content and context. In Part II, I use a pre-constitutional document, an 1822 letter from the Constitutional Congress of Peru to the Indians of the Interior Provinces, to show how pre-consitutional documents should be analyzed. My analysis of the letter illustrates how even inadvertently overlooked pre-constitutional documents, which no one expects to have any relevance today, can be used retrospectively as diagnostic tools. I critically analyze the text of the 1822 letter and show how it illustrates the tensions inherent in the relationship between Andean indigenous peoples and Creoles during Peruvian independence. Then I explore the legacy of this tension between indigenous peoples and the state in later constitutional discourses in Peru. I suggest that the 1822 letter can be used retrospectively to better understand the contemporary constitutional conflict between indigenous peoples and the state. I conclude that pre-constitutional documents matter and that using these documents as diagnostic tools increases our understanding of persistent constitutional tensions and may help to resolve them.

\section{Pre-Constitutional Documents as Diagnostic Tools}

In this Part, I argue that pre-constitutional documents matter because they may be useful as diagnostic tools for identifying tensions that emerged at the time of the constitutional order's origin and that have remained unresolved and problematic ever since. First, I define pre-constitutional documents as a genre of constitutional documents. Second, I contend that pre-constitutional documents deserve to be critically analyzed as legal documents because they often identify longstanding problems within the constitutional order. Finally, I suggest that identification of these unresolved problems and an understanding of their constitutional origins may be key to a constitutional order's attempts to resolve them.

Pre-constitutional documents are texts composed before the drafting of a final constitution that relate to the constitution-making or state formation process. Often they present the more aspirational goals of the political community that is being established. Pre-constitutional documents may come in a variety of forms, including, but not limited to, declarations of independence, ${ }^{26}$ treaties between peoples, ${ }^{27}$ proclamations, ${ }^{28}$ interim

26. See, e.g., THE DECLARATION OF INDEPENDENCE (U.S. 1776); ISRAELI DECLARATION OF INDEPENDENCE (1948).

27. See, e.g., TREATY OF WAITANGI (N.Z. 1840).

28. See, e.g., Royal Proclamation OF 1763 (U.K. 1763). 
constitutions, ${ }^{29}$ declarations of rights, ${ }^{30}$ and essays and records relating to the constitution-making process. ${ }^{31}$ Pre-constitutional documents also have a variety of purposes. Some, like the U.S. Declaration of Independence and the Israeli Declaration of Independence, assert the creation of a new governmental entity. ${ }^{32}$ Others, like the French Declaration of the Rights of Man and the Magna Carta, list the rights of individuals against the sovereign. ${ }^{33} \mathrm{~A}$ third category, including the Treaty of Waitangi and the Royal Proclamation of 1763, define the relationship between a settler colony and the indigenous inhabitants of the land. ${ }^{34}$ Pre-constitutional documents may serve other primary functions as well. ${ }^{35}$

Pre-constitutional documents constitute their own genre of constitutional documents because they are written at the commencement of the constitutional project and directly relate to that project. They tend to be initial texts which foreshadow the creation of a more definitive constitution (either written or unwritten) and outline the more aspirational goals of the political community. Unlike constitutions which "regulate the allocation of functions, powers and duties among the various agencies and officers of government, and define[] the relationships between these and the public, ${ }^{, 36}$ pre-constitutional documents are generally more fluid in their content and as noted above, may address more aspirational goals of the political community.

The unclear legal status of pre-constitutional documents also distinguishes them from constitutions and statutes. ${ }^{37}$ While constitutions and statutes are laws on the books to be strictly interpreted and used by the courts, preconstitutional documents tend to play a more fluid role politically and legally. As the debate over the central principles of the Declaration of Independence shows, pre-constitutional documents can be used in different ways by diverse peoples to tell stories about the original constitutional moment and subsequent

29. See, e.g., CONST. OF REPUBLIC OF SOUTH AFRICA (1994).

30. See, e.g., DECLARATION OF THE RIGHTS OF MAN AND OF THE CITIZEN (France 1789); MAGNA CARTA (U.K. 1215).

31. See, e.g., ThE FEDERALIST PAPERS (Clinton Rossiter ed., 1961).

32. THE DeClaRATION OF INDEPENDENCE (U.S. 1776); IsRaELI DEClaRATION OF INDEPENDENCE (1948).

33. DEClaRATION OF THE RIGHTS OF MAN AND OF THE Citizen (France 1789); MAGNA CARTA (U.K. 1215).

34. TREaty OF Waitangi (N.Z. 1840); Royal Proclamation OF 1763 (U.K. 1763).

35. For example, the primary purpose of the Federalist Papers was to advocate for the ratification of the U.S. Constitution. See generally THE FEDERALIST PAPERS, supra note 31.

36. Bogdanor, supra note 6, at 4.

37. Thanks to John Ursu for reminding me of this distinction. 
ones. Unlike the Constitution, which has gained authoritative meaning through court interpretation, the Declaration and other pre-constitutional documents are more indeterminate and open to interpretation outside the courts. For instance, President Abraham Lincoln used the Declaration of Independence to reunite the Union during the Civil $\mathrm{War}^{38}$ and President George W. Bush has hailed it as introducing god into our constitutionalism.

Pre-constitutional documents should be taken seriously within contemporary constitutional orders because they facilitate a fuller comprehension of constitutional formation by contextualizing early constitutional tensions. This contextualization provides a lens for understanding later constitutional dialogues, especially those that emerge out of initial constitutional tensions. As prologues to constitutions, pre-constitutional documents allow for contextualization and thus, better understanding of the moment of constitutional formation. They often (intentionally or unintentionally) highlight tensions in the constitutional project that may not be resolved by the final constitution.

Constitutions do not exist in isolation, but rather emerge through an evolutionary process concerned not only with the actual structure and function of the government but also with the creation of the political community. ${ }^{39}$ Often constitution-making is part of the imagination and creation of a unified political community, ${ }^{40}$ and the constitution itself contributes to the formation of this identity. ${ }^{41}$ Key to this evolution are pre-constitutional documents, which set the stage for the rest of the constitution-making process. Because preconstitutional documents play a formative role in the origins of a constitutional order, they provide insights into the original tensions faced by constitutionmakers - where these tensions came from, how they arose, and why they were central to the original constitution-making project. Gary Lawson and Guy Seidmen note how important the events occuring during constitution-making may be when they state, "[S]ome theories of governmental legitimacy might turn on the precise sequence of events in the founding era, so it is important that those events be properly recorded and understood."42 Pre-constitutional

38. Ball, supra note 3, at 2282-85.

39. For more on the evolutionary creation of constitutions, see Andrew Arato, Forms of Constitution Making and Theories of Democracy, 17 CARDOZO L. REV. 191, 198-201 (1995).

40. BENEDICT ANDERSON, IMAGINED COMMUNITIES: REFLECTIONS ON THE ORIGIN AND SPREAD OF NATIONALISM 47 (1983).

41. Larry Catá Backer, Forward: Constituting Nations - Veils, Disguises, Masquerades, 20 PENN. ST. INT'L L. REV. 329, 330 (2002) ("The instrumentalities of constitutionalism and self-determination have been used to constitute nations where none had existed before . . ..").

42. Gary Lawson \& Guy Seidman, When Did the Constitution Become Law?, 77 NoTRE 
documents help us to understand more completely founding era events with all their nuances and complexities.

Pre-constitutional documents may also provide a lens for understanding later constitutional dialogues, especially if these debates involve issues that emerged but were not resolved during constitution-making. In this sense, preconstitutional documents can serve as diagnostic tools for identifying and understanding constitutional tensions that persist long after the constitution is written and enacted.

By saying that pre-constitutional documents may be used as diagnostic tools, I make two suggestions about the place of pre-constitutional documents in contemporary constitutionalism. First, pre-constitutional documents should serve as more than mere rhetorical window dressing on our understandings of constitutionalism and they deserve to be critically analyzed like other constitutional and legal documents. In saying that pre-constitutional documents should be critically analyzed, I mean they need to be evaluated to determine whether they can be used as diagnostic tools for identifying and understanding contemporary constitutional tensions. This is not to say, however, that preconsitutional documents should become definitive, binding legal texts. I simply argue that constitutional polities need to pay enough attention to them to determine the appropriate legal, political, and cultural status to be accorded to them. Not all pre-constitutional documents may be useful as diagnostic tools or salient to the constitutional community today. Many may not be. But if preconstitutional documents are not taken seriously, we may not know if they should be or even be able to determine their full import for contemporary constitutionalism. Further, the pre-constitutional documents that inform constitutionalism today may not be the ones we think or that have retrospectively been remembered or revered.

Critical analysis will reveal which of these documents remain salient today and how they relate to contemporary constitutionalism. Such analysis will help constitutional scholars and practitioners to contextualize and better understand constitutional formation even if they discover that some pre-constitutional documents are not relevant today. Critical analysis should include a close reading of the text, including how the text imagines its own project, constitutes a community, represents the legal, political, social and cultural universe, and presents the authoritative value of its own arguments. ${ }^{43}$ Through critical

DAME L. REV. 1, 3 (2001).

43. For more information on how to read texts critically, see JAMES BOYD WHITE, WHEN WORDS LOSE THEIR MEANING: CONSTITUTIONS AND RECONSTITUTIONS OF LANGUAGE, CHARACTER, AND COMMUNITY 3-23 (1982). 
analysis, we may find that pre-constitutional documents remain relevant in unforeseen ways or identify new insights in them. ${ }^{44}$ I model critical analysis in depth in Part II.A.

Second, I am suggesting that these documents cannot be viewed in a vacuum but must be contextualized at the moment of origin and juxtaposed against later constitutional debates to reveal their full importance. In addition to a close reading of the text, our critical analysis of these pre-constitutional documents should include a survey of other key documents in the constitutional order to determine how they relate to the original document. This survey will indicate whether and how pre-constitutional documents remain relevant and contribute to contemporary constitutional politics. Part II.B provides an example of how a pre-constitutional document can be contextualized and compared to later constitutional debates.

The re-emergence of pre-constitutional documents on national political scenes demonstrates the importance of critically analyzing these documents. Recent critical analysis of the Treaty of Waitangi in New Zealand and the Royal Proclamation of 1763 in Canada has illustrated how these two documents remain central to contemporary constitutional politics.

In New Zealand, the Maaori have long argued that the Treaty of Waitangi was key to the political community, but it did not receive widespread attention until the Waitangi Tribunal started critically analyzing it in the early 1980s. The Waitangi Tribunal, which was created in 1975 as a commission of inquiry to hear Maaori grievances against the government, issued a number of reports in the late 1980 s and early $1990 \mathrm{~s}^{45}$ The reports critically analyzed the Treaty and the Treaty relationship between Maaori and the Crown. ${ }^{46}$ The Waitangi Tribunal condemned the Government for violating Treaty promises and recommended that that Treaty be considered more seriously as a legally binding foundational document. ${ }^{47}$ This critical analysis of the Treaty raised general

44. Larson argues that a thorough analysis of the Declaration of Independence helps us to better understand major issues in American public law. LARSON, supra note 1, at 701. He suggests that contrary to its usual interpretation as a declaration of thirteen states, the Declaration was a declaration of a single unified people. Id.

45. M.H. Durie, Te Mana, Te Kawanatanga: The Politics of Maori SelfDETERMINATION 184-85 (1998).

46. See, e.g., WAITANGI TRIBUNAL, THE TARANAKI REPORT: KAUPAPA TUATAHI (1996); WAITANGI TRIBUNAL, THE NGAI TAHU REPORT (1991).

47. See generally Paul TEMM, The WaItangi Tribunal: The Conscience of the NATION (1990); Kirsten Matoy Carlson, Rhetoric Versus Reality: Sovereignty and Tino Rangatiratanga in Aotearoa New Zealand 104-12 (1999) (unpublished masters thesis, University of Victoria). 
awareness of the Treaty's place in New Zealand and led to its acknowledgement as a foundational constitutional document.

Similarly, critical analysis of the Royal Proclamation of 1763 in Canada has led to its recognition as an important part of the Canadian Constitution. Like the Maaori in New Zealand, First Nations in Canada have continually maintained that the Royal Proclamation is the cornerstone of their constitutional relationship with the Canadian government. ${ }^{48}$ Only recently, however, with the Royal Commission of Aboriginal Peoples' report on the status of the relationship between Aboriginal Peoples and the Canadian government has the Royal Proclamation started to receive widespread attention as a constitutional document. ${ }^{49}$ Today Aboriginal peoples and the Canadian government are still defining their constitutional relationship, and the Royal Proclamation is increasing seen as relevant to this relationship.

While these two examples show how the critical analysis of well-known preconstitutional documents reveals their contemporary constitutional importance, I contend that even less well-known documents may serve as diagnostic tools. In the next part, I critically analyze a more obscure pre-constitutional document from Peru. My critical analysis of this less well known document demonstrates how even less popularly known pre-constitutional documents can be used as diagnostic tools to identify and understand better tensions that emerged at the moment of constitutional origin and have remained unresolved.

In arguing that pre-constitutional documents should be critically analyzed like other legal documents, I do not mean to suggest that they should also be given the same legal status. My point is simply that pre-constitutional documents should not be forgotten or ignored because they may provide important insights into contemporary constitutional debates. Pre-constitutional documents should be taken seriously because constitutional orders may learn a tremendous amount from them, but this is not to say that they should become definitive sources of constitutional law.

It may, for instance, make more sense for pre-constitutional documents to play another, albeit important role, in the constitutional order. Consider the current place of the Treaty of Waitangi in New Zealand. The Treaty has not been recognized as having definitive legal force, but it is often looked to for guiding principles in the Maaori-Crown relationship and used to interpret the law. ${ }^{50}$ Mark Tushnet argues that the Declaration of Independence should play

48. Borrows, supra note 23 , at 30.

49. See generally 2 THE ROYAL COMMISSION REPORT ON ABORIGINAL PEOPLES ch. 3.2 .3 (1996).

50. DURIE, supra note 45 , at 178. 
a similar role in the U.S. legal system. ${ }^{51}$ These views suggest that constitutional orders may view the interpretive force of pre-constitutional documents more as guidance than binding precedent. There may be reasons why a constitutional system would want to retain flexibility in how it views pre-constitutional documents because they tend to be more aspirational in nature.

Canada has taken a different approach to the question of the legal force of the Royal Proclamation of 1763. Canadian Courts have viewed it as having "the force of a statute that has never been repealed," 52 and it is mentioned in the Canadian Constitution. ${ }^{53}$ Either way, it is up to each constitutional order to decide. Once pre-constitutional documents are critically analyzed and contextualized, the legal community in the constitutional order can determine what legal status and interpretive force to accord these documents.

\section{A Case in Point: The 1822 Peruvian Letter as a Diagnostic Tool}

Peru's constitutional story did not start with the promulgation of the first national constitution of an independent Peru in November $1823,{ }^{54}$ but eleven months earlier with a letter from the Constitutional Congress of Peru to the Indians of the interior provinces. ${ }^{55}$ Written soon after Peru was declared independent in 1821 and before the end of the revolutionary war, the 1822 letter presents a story of origins; it seeks to separate Peru from its Spanish past and create something new. Constitutionalism in Peru, and particularly the relationship between indigenous peoples and the state, cannot be understood without reference to this first constitutional document. In this Part, I use the letter as a case study to illustrate how critical analysis of pre-constitutional

51. TUSHNET, supra note 4 , at 11-12.

52. R. v. Bernard, [2003] 230 D.L.R. (4th) 57, 213 (Can.).

53. CAN. Const. (Constitution Act, 1982) pt. I (Charter of Rights and Freedom) § 25.

54. The Spanish Monarchy had promulagated an earlier constitution of its own in 1812. Constitución Política de la Monarquía Española (Mar. 19, 1812), at http://www.juridicas. unam.mx/infjur/leg/conshist/pdf/1812.pdf (last visited Oct. 24, 2005).

55. I will interchangeably use the terms "indigenous" and "Indians." The definition of these terms is rather fluid, and Thornberry describes the incoherent use of "indigenous" in detail. PATRICK THORNBERRY, INDIGENOUS PEOPLES AND HUMAN Rights 2 (2003).

Currently, in Peru, the use of the term "indigenous" has replaced the more historically used "indios" because of the negative connotation attached to "indios." The same negative connotation is not attached to the English word "Indian." I have tried to use "Indian" in discussing Peruvian history to be true to the language at the time. See CHARLES F. WALKER, Smoldering Ashes: CuZCo and the CReation of Republican Peru, 1780-1840, at 11 (1999). I switch to using indigenous in Part II.B.2 to indicate the change in terminology with the development of indigenous movements around the beginning of the twentieth century. 
documents reveals how they can be used as retrospective diagnostic tools for identifying constitutional tensions present at constitution-making that remain unresolved over time. In Part II.A, I critically analyze the 1822 letter by exploring its meaning and context. This analysis suggests that the 1822 letter can be used as a diagnostic tool to identify a key constitutional tension between indigenous peoples and the Peruvian state. In Part II.B, I read the 1822 letter against later constitutional documents to illustrate how this constitutional tension persists over time, and how the 1822 letter facilitates our improved understanding of it.

\section{A. The Mystery of Meaning: Critically Analyzing an Obscure Pre- constitutional Document ${ }^{6}$}

Critical analysis of a pre-constitutional document starts with a close reading of the text. In this section, I start with some background to the creation of the 1822 letter. Then I analyze the text, including how it imagines its own project, constitutes a community, represents the legal, political, social and cultural universe, and legitimates the authoritative value of its own arguments.

As with our own story of origins, there are several options for a starting or defining moment in Peruvian history. Prior to the arrival of the Spanish, a vast Incan empire dominated South America from northern Chile, across Bolivia, Peru, and Ecuador into Colombia. The Spanish were astounded by this empire rich in silver and gold, and sought to claim its bounty for themselves. Spaniards settled along the coast and built Lima on the edge of a cliff, looking across the ocean rather than into the dense interior mountains and towards the capital of the Incans at Cuzco. After the Spanish finally defeated the Incans, ${ }^{57}$ they centered their colonial empire, the Spanish Viceroyalty in Lima in $1535 .{ }^{58}$ As the Spanish capital of Peru, Lima's architecture speaks to its Spanish origin - ornate porticos and balconies adorn the mustardy yellow Palace of the Government, which sits on the edge of a large, square Spanish-style plaza.

The Spanish dealt severely and harshly with the Indians, extracting anything and everything they could from them. ${ }^{59}$ They separated Indians from colonial

56. I primarily use my translation of the 1822 letter from Spanish to English to discuss its meaning. Any errors in translation are my own.

57. For a history of the Spanish conquest and colonization of Peru, see JAMES LOCKHART, SPANISH PERU 1532-1560: A SOCIAL HISTORY (2d ed. 1994).

58. WALKER, supra note 55 , at 7-8.

59. Lynch mentions that as late as 1800 Indians were subject to many forms of servitude. JOHN LYNCH, SPANISH AMERICAN REVOLUTIONS, 1808-1826, at 164 (1973). He argues that the cruelty of Spanish rule led to several Indian insurrections from 1756 to 1800 . Id. 
officials and created two republics; one for Indians and one for Spaniards. ${ }^{60}$ The Indians periodically rebelled, reminding the Spanish of the legendary power and empire of the Incas. ${ }^{61}$

Caught in the middle of this tumultuous dichotomy between Spanish colonials and Indians were Creoles. ${ }^{62}$ Creoles were the children of Spaniards born in America and they fit into neither the European nor Indian worlds created by the Spanish Viceroyalty. ${ }^{63}$ They were not Indians but the Spanish colonials did not consider them equals either. Creoles were treated as inferior due to their birth in America. ${ }^{64}$ They thus faced a largely schizophrenic reality in which they belonged to neither of the two republics created by the Spanish Empire. $^{65}$

The Spanish government largely collapsed in 1808 due to the arrival of Napoleon Bonaparte in Spain. ${ }^{66}$ By 1812, the Spanish had written the Cortes de Cadiz Constitution and declared America and Spain one nation. ${ }^{67}$ Under the Cortes de Cadiz, the Spanish allowed American representatives in the newly created Parliament, but it was not equal representation with their Spanish counterparts. ${ }^{68}$ These actions alienated Creoles and forced them to consider an identity separate from Spain. ${ }^{69}$ By the end of the eighteenth century, Creoles felt alienated from the Spanish by this dichotomy and some of them started to revolt against Spain. ${ }^{70}$

Uprisings, led by Indians in the Cuzco region, and Creoles elsewhere, were increasingly common in the Spanish colonies in the early nineteenth century. ${ }^{71}$ While many of these uprisings were not revolutionary in nature, by $1814 \mathrm{a}$

60. Mark Thurner, From Two Republics to One Divided: Contradictions of POSTCOLONIAL NATIONMAKING IN ANDEAN PERU 5-7 (1997).

61. WALKER, supra note 55, at 16-54.

62. Creoles were descendants born in the Americas of Spaniards who came to the new world. As Thurner notes, they were treated as inferior to Spaniards, who were born in Spain, because they were born in America. THURNER, supra note 60, at 146-47.

63. Id.

64. Id.

65. Id.

66. LYNCH, supra note 59 , at 1.

67. Id. at 35 .

68. Id. For a complete discussion on how the events in Spain and the Cortes affected Peru, see THURNER, supra note 60, at 21-23.

69. LYNCH, supra note 59, at 35-36.

70. For a discussion of the causes of the Wars of Independence in South America, see id. at $1-36$.

71. See generally id. 
Creole revolution was in motion and had reached Peru. ${ }^{72}$ A year later, Lima emerged as the base for revolutionary activities in Peru. ${ }^{73}$ But the revolution, which was imported to Peru by José de San Martín from the south and Simón Bolivar from the north, did not immediately take hold in Peru. ${ }^{74}$ Peruvian Creoles had divided loyalties. ${ }^{75}$ Some hoped to reform the Spanish Viceroyalty while others abandoned that idea and endeavored to create a new Peruvian nation. $^{76}$

Despite the arrival of the revolution, Peru would not officially declare independence from Spain until July 28, 1821-seven years after the war started. ${ }^{77}$ Shortly after Peruvian independence was declared, San Martín emerged as Peru's protector and exercised supreme civil and military power. ${ }^{78}$ San Martín forged a new national identity for Peru by decreeing the end of the Indian tribute and other forms of compulsory servitude owed by the Indians, forbidding the use of the term "Indian", and urging the recognition of everyone-including Indians-as Peruvians on August 27, 1821.79

The Viceroyalty relocated from Lima to Cuzco, ${ }^{80}$ and by September 1822 , Creole revolutionaries had convened a congress in Lima to discuss the creation of a constitutional republic. This Constitutional Congress wrote a letter to the Indians of the interior provinces. ${ }^{81}$ The letter was written in Spanish and presumably, translated into Quechua not long after it was written. ${ }^{82}$ It is

72. WALKER, supra note 55 , at $84-85$.

73. Id. at 105.

74. Id. at 106 ("Support for independence was lukewarm in Lima.").

75. Much like English settlers and their descendants in North America, not all Creoles wanted to revolt from Spain. Id. at 106-07.

76. Id.

77. LYNCH, supra note 59, at 179.

78. Id.

79. Id. at 180 .

80. WALKER, supra note 55 , at $114-15$.

81. Although it is by no means self-evident that the text was written by Creole revolutionaries, the text itself and the presence of Creole revolutionaries at the Constitutional Congress in Lima suggest that the document was written by Creole revolutionaries. While Lynch does not mention the presence of Creole revolutionaries at the Constitutional Congress, he identifies two of the signers of the 1822 letter. LYNCH, supra note 59, at xv, xx. He describes Francisco Javier de Luna Pizarro as a "Peruvian priest and republican, not entirely consistent in his attitude towards independence, but in general liberal in politics, hostile to foreign intervention in Peru and to militarism." Id. at xv. Lynch identifies José Sánchez Carrión as a "Peruvian patriot and theoretician of independence; a liberal republican, he was a minister in Bolívar's administration in 1824 and in the Peruvian government in 1825." Id. at $\mathrm{xx}$.

82. Comisión Nacional del Sesquicentenario de la INDEPENDENCIA del Perú, 
addressed to the Indians of the Andean Provinces. Its references to its own delivery and its translation into Quechua suggest that its final destination was the old Incan capital of Cuzco.

Cuzco was a world away from Lima, and largely ravished by the war. ${ }^{83}$ Although Cuzco was second only to Lima in terms of population and economic and political power, the city was largely inhabited by Indians. ${ }^{84}$ Indians had little to do with Creoles, and the Lima insurgents showed little interest in them. ${ }^{85}$ Indians existed in a completely separate social space. Geography enhanced this separation as a vast distance broken only by the peaks of the Andean mountains stretches between coastal Lima and highland Cuzco. ${ }^{86}$ The journey across this distance would have taken thirteen days. ${ }^{87}$ It would have been a long journey across linguistic, social, cultural, and geographic divides.

Creole revolutionaries were imagining a new Peru in contrast to the rule of the Spanish Empire. ${ }^{88}$ They envisioned a new republic built on enlightened liberal ideals and citizens free from the dualism of the Spanish viceroyalty. ${ }^{89}$

ANTOlogía de LA INDEPendenCia Del Perú 511-12 (1959). My assumption is that the document was originally written in Spanish and then translated into Quechua. Linguistic anthropologist and Quechua specialist Bruce Mannheim agreed with this analysis. Interview with Bruce Mannheim at the University of Michigan, Ann Arbor, Michigan (Nov. 25, 2002). Based on this assumption I am translating the Spanish as the original version of the document. I have not reproduced the Quechua version because I have not attempted to translate it into either Spanish or English. The fact that the document was translated into Quechua raises many interesting questions about how well the document translated into and was understood in Quechua. The Quechua translation appears to be a Southern or Cusqueno dialect. Id. Bruce Mannheim suggested that several differences exist between the Spanish and Quechua versions of the document and that a comparison of the two yields even more interesting questions about the creation of dialogue and community in the document. Id. Such analysis, however, will not be done here as the focus will be on the Spanish text.

83. WALKER, supra note 55, at 109.

84. Id. at 8 .

85. Id. at 120.

86. Thurner comments extensively on the geographic tension in Peru and how that maps on to social and cultural divides. THURNER, supra note 60, at 146-47 ("The cliché has been that there are two Perus: the "Peru profondo" of the "Indian" and "natural" Andean sierra, and the "modern Peru" of the "civilized," Westernized Creole coast.").

87. WALKER, supra note 55 , at 10.

88. THURNER, supra note 60, at 3 ("In Andean Peru, as elsewhere in Spanish America, the postcolonial history of nation-making was haunted by an earlier history of colonial state formation which, in the ambivalent fashion diagnostic of post-colonial nationalist predicaments everywhere, it was condemned to both negate and reclaim.").

89. Id. at 5. For a discussion of Peru's long struggle towards democracy, see Cynthia McClintock, Peru: Precarious Regimes, Authoritarian and Democratic, in DEMOCRACY IN DEVELOPING CoUNTRIES: LATIN AMERICA 313 (Larry Diamond et al. eds., 2d ed. 1999). 
Their new republic would end the formal dualism created by the Spanish viceroyalty and be distinct from both the Indian and colonial republics of the Spanish empire. ${ }^{90}$ They rejected the recognition of separate Indian communities by the Spanish and focused on the inclusion of Indians as individuals. ${ }^{91}$

While seeking to differentiate themselves from the Spanish, Creoles remembered the revolt led by Tupac Amaru in 1781-83 and were haunted by alternative visions for the new Peruvian Republic. ${ }^{22}$ They feared the reemergence of popular uprisings led by Indians seeking to re-establish the Incan empire. ${ }^{93}$ Their notions of equality and freedom, thus, ended short of reaching the Indians, who they considered inferior. ${ }^{94}$ Instead they contemplated a new republic which "would allow formerly oppressed Indians to be gradually 'enlightened' and 'civilized' so that they could 'join the rest of the free citizens' of Peru in the semi-sacred unity of the independent nation of citizens."

Against this backdrop, revolutionary Creoles assembled in a Congress in Lima wrote a letter to the Indians of the Interior Provinces. Entitled, "The Constitutional Congress of Peru to the Indians of the Interior Provinces," the letter reads: ${ }^{96}$

90. THURNER, supra note 60, at 5 ("For Creole liberals the 'Republic' in the postcolonial Republic of Peru could not be the same as the 'republic' in the colonial republic of Indians or republic of Spaniards.").

91. Sarah Chambers describes the situation in Arequipa, "[T] hose Indians who participated in republican politics would do so primarily as individuals rather than because they were represented by communal authorities." SARAH CHAMBERS, FROM SUBJECTS TO CITIZENS: HONOR, GENDER, AND POLITICS IN AREQUIPA, PERU, 1780-1854, at 61 (1999).

92. Tupac Amaru, or José Gabriel Condorcanqui, led the largest rebellion in Spanish American colonial history from 1781-83 before being captured and beheaded by the Spanish authorities in Cuzco. WALKER, supra note 55, at 16. For more information on Tupac Amaru, see id. at 16-54.

93. THURNER, supra note 60 , at 4, 9-10.

94. Id. at 10 ("And for Bolivar, "no Indian could be the bearer of a significant past or the spiritual leader, however fictionalized, of a republican future. For the most part Bolivar thought of Indians [with the exception of the romanticized 'untamed Araucanians' of Chile], when at all, as an essentially docile, unpoliticizable mass that 'wishes only for rest and solitude."').

95. Id. at 5.

96. The Spanish version of the document reads:

El Congreso Constituyente del Perú a los Indios de las Provincias Interiores

Nobles hijos del sol, amados hermanos, a vosotros virtuosos indios, os dirigimos la palabra, y no os asombre que os llamemos, hermanos: lo somos en verdad, descendemos de unos mismos padres; formamos una sola familia y con el suelo que nos pertenece, hemos recuperado también nuestra dignidad y nuestros derechos. Hemos pasado más de trescientos años de esclavitud en la humillación 
más degradante y nuestro sufrimiento movió al fin a nuestro Dios a que nos mirase con ojos de misericordia. El nos inspiró el sentimiento de Libertad y el mismo nos ha dado fuerza para arrollar a los injustos usurpadores, que sobre quitarnos nuestra plata y nuestro oro, se posesionaron de nuestros pueblos, os impusieron tributos, nos recargaron de pensiones y nos vendían nuestro pan y nuestra agua. Ya rompimos los grillos, y este prodigio es el resultado de vuestras lágrimas y de nuestros esfuerzos. El Ejercito Libertador que os entregará esta carta lo enviamos con el designio de destrozar la última argolla de la cadena que os oprime. Marcha a salvaros y protegeros. El os dirá y hará entender que están constituidos; que hemos formado todos los hijos de Lima, Cuzco, Arequipa, Trujillo, Puno, Huamanga y Huancavelica, un Congreso de los más honrados y sabios vecinos de esas mismas provincias. Este Congreso tiene la misma y aun mayor soberanía que la de nuestros amados Incas. El, a nombre de todos los pueblos, y de vosotros mismos, va a dictar leyes que han de gobernarnos muy distantes de las que nos dictaron los injustos reyes de España. Vosotros indios, sois el primer objeto de nuestros cuidados. Nos acordamos de lo que habéis padecido, y trabajamos por haceros felices en el día. Vais a ser nobles, instruidos, propietarios, y representareis entre los hombres todo lo que es debido a vuestras virtudes.

Esperad muy breve el cumplimiento exacto de estas promesas que no son seguramente como los falsos ofrecimientos del gobierno español. Aguardad también nuestras frecuentes cartas, nuestras determinaciones, y nuestra constitución. Todo os irá en vuestro idioma quechua, que nos enseñaron nuestros padres y que mamasteis a los pechos de vuestras tiernas madres.

!Hermanos!: el día que recibáis esta carta veréis a vuestro padre el sol amanecer más alegre sobre la cumbre de vuestros volcanoes de Arequipa, Chachani, Pichupichu, Coropuna, Sulimana, Sarasara, Vilcanota, Ilimani. Abrazad entonces a vuestros hijos, halagad a vuestras esposas, derramad flores sobre las hueseras de vuestros padres, y entonad al son de vuestro tambor y vuestra flauta dulces yaravies, y bailad alegres cachuas diciendo a gritos; ya somos nuestros; ya somos libres; ya somos felices.

En la ciudad de Lima, a 10 de Octubre de 1822 años. - Javier de Luna Pizarro, Presidente. - José Sánchez Carrión, Diputado secretario. - Francisco Javier Mariátegui, Diputado secretario.

Translating the document into English was challenging because translating a document from one language into another forces the translator to reconcile differences between the two languages that are not easily reconcilable due to the intricacies of both languages. While attempting to be true to the text, the English translation loses something in the process.

First, I had to alter slightly the verb forms to clarify direct and indirect objects. While this does not change the meaning of the text, it alters the flow slightly. The Spanish language uses a reflexive verb form, which indicates the addressee and does not exist in English. I have eliminated many of these references because the same form is not used in English (where the intended audience is understood) and literal translation interrupted the flow of the sentences. Similarly, due in part to the reflexive form, what is considered an unclear antecedent in English is often not unclear in Spanish due to verb endings which are specified and provide more 
Noble sons of the sun, beloved brothers, to you virtuous Indians, we address the word, and do not be astonished that we call you, brothers: we are in truth, we descend from the same fathers; we form only one family and belong to the same native land, we have also regained our dignity and our rights. We have passed more than 300 years of slavery in the most degrading humiliation and in the end our suffering moved our God to see us with eyes of mercy. He inspired in us the sentiment of Liberty and the same has given us the strength to destroy the unjust usurpers, that take from us not only our silver and our gold, but that also possessed our towns, imposed tributes, overloaded us with anxiety and sold our bread and water. Already we broke the fetters, and this miracle is the result of your tears and our courage. The Liberation Army that will deliver this letter that we send you with the purpose to cut to pieces the last

information than their English counterparts, which have to be modified with details about the speaker, direct object, and the person addressed. In the text, this led to some places, in which a pronoun needed to be replaced with the specific noun in English. Accordingly, I replaced "el" with "the army" and "the Congress" to clarify the meaning of the document.

J.B. White describes a similar difference in verb endings in his comparison of English and Greek. He explains,

Every finite verb has endings that tell you whether the actor is one person or more, and whether the actor is the speaker, the person addressed, or a third person; whether the action takes place in past, present, or future time; whether it is continuative, punctual, or completed; whether it is a simple description of a fact (indicative) or expressive of hopes, fears, wishes, or commands (modal). And so on. None of these words can appear "bare," without any syntactic indicators, such as "house" or "person," say, can in English. The effect of such a structure is that it makes possible a different kind of sentence, and a different kind of thought, from anything that we do in English.

WHITE, supra note 43 , at $75-76$.

Second, certain words were particularly difficult to translate because the English words do not carry the same connotation or meaning as the Spanish. Here the meaning assigned becomes crucial because native English speakers run the risk of interpreting words without fully understanding the meaning assigned to them in Spanish. White also addresses this point. He states, "what occasions language, what calls for speech, may not be naming of things - we can point after all - but a sense of their meaning for us." Id. at 84 . I have tried to note these lapses in translation in the analysis of the text.

Finally, in the translation of metaphors and similes, I tried to minimize the loss of meaning where possible. In doing this, I kept in mind the fact that the text was probably meant to be proclaimed rather than read silently.

A lot more could be said about the differences between the two languages and how that affects translation. For a more detailed discussion of these kinds of problems, see $i d$. at 69-103. 
large iron ring of the chain that oppresses us. It marches to save and protect you. The army will give you and make you understand that it is constituted; that we, all the sons of Lima, Cuzco, Arequipa, Trujillo, Puno, Huamanga and Huancavelica, have formed a Congress of the most honorable and wise neighbors of these same provinces. This Congress has the same and even greater sovereignty of our beloved Incas. The Congress, in the name of all the communities and of your same, will dictate laws that will govern us very differently than those that were dictated by the unjust kings of Spain. You Indians are the first object of our attention. We agree that you have suffered and we work to make you happy in the day. You will be noble, well-educated, property owners and you will represent among men all that is owed to your virtues.

Await very shortly the exact fulfillment of these promises that are trustworthy unlike the false offerings of the Spanish government. Await also our frequent letters, our resolutions and our constitution. All will be in your language quechua, that we were taught by our fathers and that you suckled at the breasts of your affectionate mothers.

Brothers!: the day that you receive this letter you will see your father the sun rise very bright about the summit of your volcanos of Arequipa, Chachani, Pichpichu, Coropuna, Sulimana, Sarasara, Vilcanota, Ilimani. Embrace your sons, praise your wives, spread flowers about the graves of your fathers and sing traditional songs of your drum and your sweet flute, and dance happy traditional dances exclaiming; already we are our own [men]; already we are free; already we are happy.

In the city of Lima, on 10 October 1822 . Javier de Luna Pizarro, President. - José Sánchez Carrión, Deputy secretary. Francisco Javier Mariategui, Deputy secretary. ${ }^{97}$

The immediate impact of the letter is difficult to determine. From its own internal references, it was to be delivered to the Indians in the Cuzco region and other highland locations. While it is not clear that the document was ever delivered, the childlike quality of the Spanish language used indicates that the

97. Letter from the Constitutional Congress of Peru to the Indians of the Interior Provinces (Oct. 10, 1822) (on file with author). 
document was meant to be proclaimed orally rather than read silently. ${ }^{98}$ Most likely, if the document was ever proclaimed, it was read in Quechua as well as Spanish. ${ }^{99}$ Such governmental proclamations were common, but how the Indians responded to the letter is unknown. If the Indians did receive the letter, it did not inspire them to join the war effort. By 1822, Indians, who were as ambivalent about the independence movement as Creoles, were not large-scale participants in the War of Independence. ${ }^{100}$

The letter has been the subject of little commentary, but it has been reproduced regularly and is often found in anthologies of early Peruvian documents and collections of Peruvian constitutions. ${ }^{101}$ Andean historians, legal scholars, and anthropologists are aware of its existence, ${ }^{102}$ and some Peruvian constitutional law scholars assert it is key to understanding Peruvian constitutional history. ${ }^{103}$ Its continued reproduction and mention in scholarly circles indicates that even though it has not been widely analyzed, it has been consistently recognized as part of Peruvian history and constitutionalism.

The letter's legacy lies in that it raises issues about the political community that continue to pervade Peruvian constitutionalism, nationalism, and political society. ${ }^{104}$ Independence was a key moment in the formation of the Peruvian political community. Historian Sarah Chambers explains, "[i]ndependence initiated negotiations over citizenship-its respective rights and obligations as

98. One of my Spanish colleagues, Julen Etxabe, suggested that the childlike language used in the document indicates that it was written to be read aloud and most likely would have been delivered orally. What actually happened, however, is unclear.

99. The possible oral delivery of the document raises several questions and issues that will not be explicitly addressed here. Bruce Mannheim suggested that the translation of the text into Quechua would not have been understood by all of the indigenous peoples of the interior provinces because some of them would either not have spoken Quechua or not have understood this dialect. Interview with Bruce Mannheim, supra note 82. This may indicate that the actual audience was more a romanticized idea of the descendants of the Incas (who spoke Quechua) than the Indian population of the interior provinces.

Further I have no information on who translated the document or the quality of the translation of the Spanish into Quechua. Translations of communications of contact, including treaties, have been known to be notoriously bad and this one could be as well.

100. WALKER, supra note 55, at 118 ("The Indian population in the Cuzco region had never been homogeneous, but the fragmentary application and impact of the late colonial reforms increased inter- and intracommunity differences, a fact that helps explain the multiplicity of strategies adopted during the long War of Independence.").

101. See, e.g., COMISIÓN NACIONAL DEL SESQUICENTENARIO DE LA INDEPENDENCIA DEL PERÚ, ANTOLOGIA DE LA INDEPENDENCIA DEL PERÚ 511-12 (1959).

102. Interview with Bruce Mannheim, supra note 82.

103. Anonymous interview, Universidad de Católica, Lima, Perú (July 2002).

104. See supra Part II. 
well as its boundaries of inclusion and exclusion - that have remained at the center of political movements in Latin America . . until today." 105 The 1822 letter helps us to contextualize this moment and see how it shaped Peruvian constitutionalism.

Close to two centuries after the writing of the letter, Peru's constitutionmaking and nation-making projects remain incomplete. Peruvian sociologist Sinesio López explains, "Peru is a nation in formation. Independence did not resolve the national problem produced by the conquest and colonization that set distinct economic, cultural and racial societies against one another." ${ }^{106}$ The 1822 letter suggests some of the reasons why this process remains incomplete. It enhances our understanding of later attempts to complete it and informs the formation of Peruvian nationalism and constitutionalism that continues today.

I have represented the 1822 letter as a pre-constitutional document central to Peruvian constitutionalism much like the Declaration of Independence in the United States and yet simultaneously admitted that the impacts of the letter are unknown, at best more ambiguous than those of the Declaration, which we ritualistically celebrate every Fourth of July. What is it about this letter, that retrospectively makes it so key to Peruvian constitutionalism? A closer look at the letter reveals the constitutional tensions that it identified and that have remained unresolved in the present.

\section{To Whom, From Whom, For What: Constituting A Community}

The document is a letter from the Constitutional Congress of Peru to the Indians of the Interior Provinces seeking to identify the Indians with the cause of that revolutionary constitution-making body. It commences:

Noble sons of the sun, beloved brothers, to you virtuous Indians, we address the word, and do not be astonished that we call you, brothers: we are in truth, we descend from the same fathers; we form only one family and belong to the same native land, we have regained also our dignity and our rights. ${ }^{107}$

105. CHAMBERS, supra note 91 , at 3.

106. Sinesio López, De Imperio a Nacionalidades Oprimadas: Notas Sobre el Problema Nacional Indigena, in NUEVA HISTORIA GENERAL DEL PERÚ: Un COMPENDIO 231 (1979) ("El Perú es una nación en formación. La independencia no pudo resolver el problema national producido por la conquista y la colonia que contrapusieron los sociedades distinctas económica, cultural y racialmente."). Translation in text by author.

107. Letter from the Constitutional Congress of Peru to the Indians of the Interior Provinces, supra note 97. 
This introduces not just a letter, but a very personal and informal one. It explicitly addresses "brothers" and constructs an imagined familial relationship between the writer and the recipient Indians. It is as though the author is speaking to a community that already exists - the family as community rather than creating one. ${ }^{108}$ The document, thus, constitutes a community by pretending like it is not creating one. It appeals to a sense of nation based on the common birth of Creoles and Indians in Peru and their universal tie to a native homeland. Yet simultaneously the document acknowledges the Indians as separate from the Creoles by recognizing that they are the "sons of the sun" and the direct descendants of the Incas. ${ }^{109}$ In an odd turn, the letter almost breaks its imagined community with this reference to outside, uncommon ties.

Even with the hint of a break here, the text does not abandon its initial focus on creating a unified community through a close familial relationship between Creoles in Lima and Indians in the highlands, but reaffirms the close relationship between the two groups through an appeal to shared experiences. The letter states,

We have passed more than 300 years of slavery in the most degrading humiliation and in the end our suffering moved our God to see us with eyes of mercy. He inspired in us the sentiment of Liberty and the same has given us the strength to destroy the unjust usurpers, that take from us not only our silver and our gold, but also that possessed our towns, imposed tributes, overloaded us with anxiety and sold our bread and water. ${ }^{110}$

By appealing to a shared experience, namely the fate they both suffered under Spanish rule, the text reinforces the idea of a unified community that is inclusive of both the writer and the recipient. Similarly, in very clear ways, the text distinguishes itself from previous documents of the viceroyalty. For instance, the text identifies the Indians in a familiar, similar way rather than

108. In Spanish, the text enhances the idea of the personal and familiar through the use of the "vosotros" form, which is the form for the informal plural you, instead of the more formal "ustedes" form. AMERICAN HERITAGE SPANISH DictionaRY xiv, § G33 (1986).

109. Calling the Indians "sons of the sun" acknowledges the spiritual link between the Incans and the sun. Arguably, this phraseology recognizes and honors the link between the Indians and the Incans and can be interpreted as an accolade to the Indians. A more cynical reading, however, may suggest that the Creoles intended to claim descendency from the Incans themselves as a way to justify their own sovereignty from Spain.

110. Letter from the Constitutional Congress of Peru to the Indians of the Interior Provinces, supra note 97. 
subjecting them to tributes, taxes, and indentured servitude - all of which were common hallmarks of the Spanish viceroyalty. ${ }^{111}$ The letter pursues this desire to create a unified community in its appeal to the sovereignty of the Incas, its inclusive description of the Constitutional Congress, and its use of the geography of the Andes. ${ }^{112}$

\section{Shapeshifting to Obscure an Ambiguous Universe ${ }^{113}$}

This initial interpretation of the document as a letter written by Creole revolutionaries to highland Indians to create a unified community involved in the making of a new constitution and nation presents one way of understanding how the letter imagines its own project. This interpretation, however, oversimplifies both the intricacies of the document and the complexities of the time in which it was written. It overlooks an important ambiguity in how the text describes its project and the surrounding universe. A closer look at how the letter represents the legal, political, social and cultural universe indicates how the notion of a familial relationship and a commonality of experience between Creoles and Indians contradicts other references made in the text about Indians.

The focus in the document shifts about half way through the first paragraph when a distinction (arguably foreshadowed in the first sentence, which identifies the Indians with the Incas by calling them "sons of the sun") between Indians and Creoles emerges. The text submerges this move through the dual use of the word "we" within the first paragraph and hides it from the reader, leaving the original fiction of a unified community. Only close attention and

111. LYNCH, supra note 59, at 164.

112. Interestingly enough, the regions mentioned extend beyond the state of Peru today and into present-day Bolivia by referring to Ilimani, which is the main Andean peak towering above La Paz, Bolivia.

113. Many native Indian tribes in North America speak of a concept of shapeshifting and shapeshifters or tricksters. See, e.g., AMERICAN INDIAN TRICKSTER TALES (Richard Erdoes \& Alfonso Ortiz eds., 1998). Shapeshifters or tricksters are often not what they seem. Gerald Vizenor, Trickster Discourse: Comic Holotropes and Language Games, in NARRATIVE CHANCE POSTMODERN DISCOURSE ON NATIVE AMERICAN LITERATURES 187-208 (1989). For example, the coyote is often characterized as the most famous of the shapeshifters because of his ability to shift deceptively from one form of being, such as coyote to another, such as raven or human, and then back to his original form. Often the shapeshift occurs so quickly that it is unidentifiable to human senses of perception. I use this concept here because it describes a transition in identity that can also be applied to a series of transitions in the text, which seek to obscure the identity of and relationship between the speaker and the audience. For other references to the idea of the shapeshifting in legal language, see John Borrows, Frozen Rights in Canada: Constitutional Interpretation and the Trickster, 22 AM. INDIAN L. REV. 37 (1997). 
an attentive ear would have picked up on the shift and it may have been intentionally manufactured to brush over an imperfection in the imagined community that the text tries to create. ${ }^{114}$

The shift occurs when the "we" changes from being "we" the Indians and Creoles to being "we" the Creoles. The move suggests that a "you" and an "us" exists within the universal "we" that the document initially attempts to create. The move changes quickly to blur the result. ${ }^{115}$ Subtly, this shift emerges in the following sentence:

Already we broke the fetters, and this miracle is the result of your tears and our courage. ${ }^{116}$

Here, the "we" no longer refers to Indians and Creoles as a unified community, but only to the Creoles, who responded with "their" courage to the tears of the Indians. The change is more accentuated in the next sentence:

The Liberation Army that will deliver this letter that we send you with the purpose to cut to pieces the last large iron ring of the chain that oppresses us. ${ }^{117}$

Again, the implied "we" of the text exists as exclusive rather than inclusive of the recipient "you" of the letter. The "we" is then clarified as the Liberation Army sent by the Constitutional Congress. And yet the same sentence ends with a return to the original claimed community by implying the Spanish oppresses both of "us."

With the recognition of the Liberation Army as the deliverers of the letter, the initial fiction of a unified community of Indians and revolutionaries breaks down despite the struggle to retain the fiction through the use of "us" at the end of the sentence. This breakdown was inevitable given the social relations at the time of the revolution. As already mentioned, historians have long documented the fragmentation of the Peruvian population during the revolution. ${ }^{118}$ Rejected by the Spaniards for being born in America, the revolutionaries faced internal

114. I wonder if this subtle shift exists in the Quechua translation and could have been identified at delivery.

115. This shift works more magically in Spanish, which due to specified verb endings is less pronoun reliant than English. See supra note 96. In Spanish, the shift is hidden in the verb ending, which makes it less obvious than the change in pronouns evident in the English translation.

116. Letter from the Constitutional Congress of Peru to the Indians of the Interior Provinces, supra note 97.

117. Id.

118. See, e.g., LYNCH, supra note 59, at 157. 
anguish over their status as "Americans" rather than Europeans or Spaniards. ${ }^{119}$ Consequently, this increased the tension in their relationship with the Indians. ${ }^{120}$ Historian Mark Thurner explains

Indeed, the Creole nationalist identification with America presented inevitable and transparent contradictions - of which Bolivar himself was well aware - given the historically deeper claims to native status made by rival Andean or Indian elites and their communities. As Bolívar confessed:

"Americans by birth and Europeans by law, we [Creoles] find ourselves engaged in a dual conflict, disputing with natives for titles of ownership, and at the same time struggling to maintain ourselves in the country of our birth against the opposition of the [Spanish] invaders. Thus our position is most extraordinary and complicated." 121

A deep geographical divide fragmented revolutionary Peru just as much as social and linguistic differences. ${ }^{122}$ Concentrated in Lima with a small population in Cuzco, the Creoles remained alienated geographically as well as socially and linguistically from the Indians (and the Spanish).

Due to the social, cultural, and geographical stratification in revolutionary Peru, the Creoles, with only a minority of the population, were stuck between a rock, the Spanish Empire, and a hard place, native Peru. The letter appears to be an attempt to resolve the Creoles' predicament through a negotiated alliance with the Indians. To use a contract metaphor, the letter appears to be an offer to the Indians to join the Creoles. ${ }^{123}$ At the same time, it is only the beginning of negotiations over the new Peruvian state and it is not clear that the Creoles were committed to negotiating with and including the Indians. While the letter hints at inclusion and a more equal partnership between Creoles and Indians, the letter does not clearly express what the Indians would receive in exchange for allying with the Creoles against the Spanish.

A shift in tone follows the change in who is identified by the text as constituting the "we" in the letter and provides some clues as to why Creoles wrote the letter. The tone transitions from declaratory to persuasive; it encourages the Indians to join the Creoles in their military and constitutional

119. THURNER, supra note 60 , at 4 .

120. Id.

121. Id.

122. See supra text accompanying note 88 .

123. Thanks to Craig Lawler for suggesting the contract metaphor. 
pursuits rather than acknowledges a pre-existing community between the two. The next sentence provides Indians with reasons for joining the revolutionaries:

The army will give you and make you understand that it is constituted; that we, all the sons of Lima, Cuzco, Arequipa, Trujillo, Puno, Huamanga and Huancavelica, have formed a Congress of the most honorable and wise neighbors of these same provinces. ${ }^{124}$

Not only does the ambiguity between "we" as including Creoles and Indians and "we" as just Creoles persist, but the tone shifts to a paternalistic concern for the Indians. The Spanish version expresses a strong sense of paternalism in the sentence and it loses some of its meaning in the English translation. The terms translated here as "honorable" and "wise," imply a lower social status not apparent in English. ${ }^{125}$ The use of these terms indicates that the speaker is talking down as though this social division were the natural state of the world.

The paternalism increases in the next couple of sentences. Consider the following:

The Congress, in the name of all the communities and of your same, goes to dictate laws that will govern us very differently than those that were dictated by the unjust kings of Spain. You Indians, are the first object of our attention. We agree that you have suffered and we work to make you happy in the day. You will be noble, welleducated, property owners and you will represent among men all that is owed to your virtues. ${ }^{126}$

It is as though the promise of a paternalistic relationship was the only way Indians could be persuaded either to join or at least not to oppose the Creoles. Notice that the Constitutional Congress, which seeks to represent the Indians'

124. Letter from the Constitutional Congress of Peru to the Indians of the Interior Provinces, supra note 97.

125. The Spanish "sabios" and "honrado" translate loosely into wise and honorable, but both indicate a status that is not attributed to their English counterparts. Whereas, "sabios" suggests a kind of wisdom acquired later in life, such as that of an elder in the community, wise has a broader application in English. My understanding of "sabios" is that it suggests a kind of wisdom attributable to someone who has seen much of life. Examples of who has "sabios" would include a grandfather figure, such as father time, or a distinguished elder in a native community. Similarly, "honrado" goes to a kind of honesty or integrity possessed by a good person of a lower social status in Spanish, which is not part of the meaning of honorable, the English word I have chosen. Thanks to Julen Etxabe for helping to clarify the distinctions between the Spanish meanings and their English translations.

126. Letter from the Constitutional Congress of Peru to the Indians of the Interior Provinces, supra note 97. 
interests and make them "happy in the day," does not contain representatives of the Indians. Rather, the "Indians are the first object" of the Creoles' attention and the Creoles promise a better (if not more representative) regime than the tyranny of the Spanish. This weak promise does not guarantee that the Creoles would actually replace the Spanish with something better and leaves open the possibility of a new Creole regime that was equally bad if not worse for Indians. The Creoles' paternalistic instruction to the Indians that they will be "noble" and "well-educated" suggests that they attributed to the Indians the same lowly status as did the Spanish.

With this paternalistic instruction, another contradiction (or perhaps another manifestation of the same contradiction) emerges. Despite the description of Indians as noble in the first sentence of the document, the instruction "to be noble" suggests otherwise. Why will the Indians be noble if they are noble already? This paternalism appears to undercut the fiction of a unified community of Indians and Creoles and serves as another example of the larger tension in the text about the relationship between them. It also arguably undermines the earlier implied argument by Creoles that the Indians should join them because they were all part of the same community with the same family, experiences, and rights. The extension of paternalism here suggests that this first argument may have been a pre-text to garner Indian support.

The paternalism suggests that social stratifications will remain even after the Spanish are gone and that inequalities between communities will continue. This undercuts the Creole promise of a new constitutional order based on equality and protective of the Indians. ${ }^{127}$ Paternalism returns in the next paragraph when the Creoles instruct the Indians:

Await very shortly the exact fulfillment of these promises that are trustworthy unlike the false offerings of the Spanish government. Await also our frequent letters, our resolutions and our constitution. ${ }^{128}$

This "await for our resolutions and our constitution" is followed by a promise, in the form of an emotional statement about mothers and fathers, to demonstrate the good intentions of the Creoles, and reiterate the original fiction of a unified community between Creoles and Indians.

127. Thurner suggests that status distinctions not only remained after the creation of the Republic, but in some ways worsened. THURNER, supra note 60, at 137 .

128. Letter from the Constitutional Congress of Peru to the Indians of the Interior Provinces, supra note 97. 
All will be in your language quechua, that we were taught by our fathers and that you suckled at the breasts of your affectionate mothers. ${ }^{129}$

Although the promise here is clear, we will include you in our constitution and our nation through the use of your language, the rest of the sentence is an enigma, perhaps reflective of the larger ambiguity in the document about the relationship between Indians and Creoles. The sentence obscures what the constitutional relationship between the two will be. The changes in tone and in the definition of the community shift so rapidly and so often (sometimes even within the same sentence) that it is hard to tell. The ambiguity and the tension between indigenous and Creoles that it produces are the most important and persistent message in the text.

\section{Looking for Legitimacy Between a Rock and a Hard Place}

If indeed the Creoles were between a rock and hard place, with the rock being the Spanish Viceroyalty and the hard place being the Indians, why try to resolve it by writing a letter to the Indians? Simply, the Indians could numerically assist in the defeat of the Spanish. But the Creoles seem somewhat uncomfortable, or at the very least ambiguous about such an alliance, and uncertain, if not outright squeamish, about allowing any participation by Indians in the new constitutional regime. If they did not want the Indians to join them (at least not in the governing aspects of the new regime), what did the Creoles want? This communication was written during the revolutionary war, four years before the liberation of Peru was complete, and one year before the enactment of Peru's first constitution. ${ }^{130}$

The interpretation of one tricky sentence, slid sneakily between the monotonous but puzzling ambiguity of the persuasive language and the paternalistic cares in the first paragraph is central to investigating the letter: This Congress has the same and even greater sovereignty of our beloved Incas. Wait a minute - sovereignty? What has that got to do with anything? Why appeal to Incan sovereignty?

Perhaps sovereignty has everything to do with it. After all, European nations, including the Spanish, used their colonies in the Americas as a way to solidify their own sovereignty. ${ }^{131}$ The Spanish had to subjugate the powerful

129. Id.

130. Id. at 187 .

131. See generally Jens BARTELSON, A GenEALOGY OF SOVEREIGNTY (1995); PATRICIA SEED, CEREMONIES OF POSSESSION IN EUROPE'S CONQUEST OF THE NEW WORLD, 1492-1640 
Incan Empire, which stretched from Colombia to Chile, before laying claim to Peru. When the letter was written, the Creoles were trying to solidify their own sovereignty claims. They had already convened a Constitutional Congress; they were in the process of creating a new nation-state and would issue their first formal constitution within a year. They appeared to be trying to legitimize their new regime by appealing to their status as native-born Americans and thus, by association, descendants of a greater Incan sovereignty. The Creoles may have been trying to include the Indians via an appeal to Incan sovereignty. In a swift rhetorical move, they disguised the fact that they had no other claim to legitimacy. (Even though they had declared independence,) They had not won the war with Spain. Note, however, that even here Creoles revolutionaries could not resolve their ambiguous relationship with the Indians; they recognized the sovereignty of the Incas, not the sovereignty of the Indians. In doing this, they romanticized the fallen Incan empire, the deceased glory rather than the less impressive present status of the subjugated Indians. And this could be how they managed to claim sovereignty for themselves - they were not usurping the sovereignty of the current Indians, but appealing to an older one, which they as natives to America also inherited. ${ }^{132}$

Thurner identifies the Creoles' technique: "When Peruvian Creoles did turn their imaginative attention to the Andean heritage (which was rare), they routinely juxtaposed the once great but ostensibly vanished civilization of the Inka against the degenerate and inferior 'Indian race' that surrounded them." 133 The juxtaposition between Incas and Indians provided the Creoles with a way to navigate between the rock and the hard place. The Creoles appealed to the nostalgia of the once-great but now subjugated past which provided distance from the Spanish and legitimized the claimed sovereignty of a new, independent Peruvian state, but did not fully alienate or include the Indians.

\section{Full Circle}

The final paragraph in the letter loops back to the original praise given to the Indians by the Creoles in a typical rhetorical turn (in English at least). In the end, the document comes full circle, returning to the tone of admiration for Indians and the creation of a unified community between Indians and Creoles upon which a new, independent constitutional Peruvian nation could be built.

(1995).

132. A similar move is also occasionally made in United States' literature about Native Americans. The author uses the idea of "dead" or historicized Indians to make a claim for an inheritance from them. See, e.g., WILla CATHER, THE Professor's HOUSE (1925).

133. THURNER, supra note 60 , at 10. 
Almost predictably the last paragraph repeats the same call to brotherhood that commences the letter as a whole:

Brothers!: the day that you receive this letter you will see your father the sun rise very bright about the summit of your volcanos of Arequipa, Chachani, Pichpichu, Coropuna, Sulimana, Sarasara, Vilcanota, Ilimani. Embrace your sons, praise your wives, spread flowers about the graves of your fathers and sing traditional songs of your drum and your sweet flute, and dance happy traditional dances exclaiming; already we are our own [men]; already we are free; already we are happy. ${ }^{134}$

The Creoles returned to the tone abandoned in the middle of the document. They wished to leave the Indians not with the divisive paternalism central to the heart of the document but with a sense of unity.

The text has a strategy to it: start with flowery language and an admiring tone about the connection between the Indians and the author, break inconsistently - somewhere in the middle from this tone and take up a more paternalistic and authoritarian one, then return to the original niceties at the end. ${ }^{135}$ The text here aspires to create an imagined community between Creoles and Indians that it abandons halfway through the document and then returns to in the end. This completion of the circle, by beginning and ending on the same note, submerges the shifts within the document even more than the initial, inconsistent shifts themselves. The Creoles appear to have taken the advice about beginning and ending with what you want your audience to remember because they replicate it here by reiterating that the Indians are their brothers and suggesting that the new Republic will bring the light of a new, happier day to the Indians.

Although such a strategy demonstrates how the authors may have used the ambiguity of their relationship with the Indians to develop the arguments they make in the document and encourage (or manipulate) Indians to act in certain

134. Letter from the Constitutional Congress of Peru to the Indians of the Interior Provinces, supra note 97. My translation of the metaphor "a vuestro padre el sol amanecer mas alegre sobre la cumbre" clearly loses some of the original meaning, which suggests that a new day is rising for the Indians upon the receipt of the letter. To translate the metaphor to ensure this meaning would obscure another important meaning in the sentence, namely that of the sun as the father of the Incas and the link to indigenous Andean religion. Because of the focus on the relationship between indigenous peoples and the author of the text, I choose to obscure the first meaning about a new day rising in order to emphasize the connection between the Incas and the sun god.

135. Thanks to Carsten Hoppe for suggesting this "strategy." 
ways, the strategy does not resolve any of the underlying tensions in the document. The indeterminate relationship between Indians and Creoles remains and I am left with the same question I started with: Are the Indians part of the political community, constitution, and nation of the new Republic, as defined in this document, or not?

This lingering question nicely expresses the constitutional tension between indigenous peoples and Creoles identified by the 1822 letter at the time of constitution-making. It suggests the text's underlying struggles to coherently imagine its own constitutional project, to create a unified community in a new Peruvian Republic, and to legitimate its own sovereign authority amidst a revolutionary war. The Creoles' ambiguity towards indigenous peoples reflects the contradictory ways in which they perceived their legal, political, social and cultural universe. This tension between indigenous peoples and Creoles, first identified at the moment of constitutional origin, remains unresolved in Peruvian constitutionalism today.

\section{B. A Relic's Contemporary Relevance: How the 1822 Letter Informs Constitutional Politics Today}

In this part, I survey Peruvian constitutional documents to demonstrate how the tension in the 1822 letter about the constitutional status of indigenous peoples continually reemerges in Peruvian constitutional discourses. This brief history of Peruvian constitutional politics situates the 1822 letter at the moment of constitutional origin and compares it to later constitutional politics. This contextualization illustrates how the dialogue about the inclusion of Indians in the 1822 letter has persisted. ${ }^{136}$ The tension in the 1822 letter has resurfaced regularly throughout Peruvian constitutional history and it prompted later constitutional debates over the relationship between indigenous peoples and Creoles. While tensions in the 1822 letter largely frame the discourse, the contours of the debate shifted as responses to the tension changed. I focus on substantive provisions of Peruvian constitutions to illustrate how the tension identified in the 1822 letter has shaped Peruvian constitutional politics historically. These constitutional provisions are informative because Creoles

136. This article does not comprehensively review the historical sources and does not aim to resolve any historical issues. My focus is more illustrative: to show a brief historical description of the nation as defined by political elites through constitutional provisions. I do not consider how indigenous peoples perceived themselves within the new Republic but rather look at official statements issued by Creole governments in constitutions. For information on how indigenous peoples contested the notions of citizenship embodied by the new nation, see THURNER, supra note 60; CHAMBERS, supra note 91; WALKER, supra note 55. 
often used constitutions to help define and consolidate the nation. ${ }^{137}$ These substantive constitutional provisions document how the debate has developed over time and how Peruvian constitution-makers continue to respond to the tensions in the 1822 letter. The interchange between texts illustrates the persistence of the original tension and how it continues to shape the state's relationship with indigenous peoples. The highlighting of the origin and persistence of this tension facilitates a more complete understanding of Peru's longstanding constitutional ambivalence towards indigenous peoples.

\section{Persistent Problems: The Ambiguous Constitutional Status of Indigenous Peoples in Nineteenth Century Peru}

Early Peruvian constitutions indicate that the Creoles' hesitancy towards Indians continued in the formative years of the new republic. ${ }^{138} \mathrm{~A}$ comparison of early Peruvian constitutional provisions on citizenship and nationality demonstrates that the question was not only whether to include Indians but how to include them. The 1822 letter half-heartedly invited the Indians to join the new community to be solidified by Peruvian independence and constitutionalism. ${ }^{139}$ The letter, however, fell short of these promises by failing

137. The role that constitutions played in the Creoles' nation-making project emerges in the texts that they created and the language that they used to address who would and would not be included as citizens and voters in the new nation. They used constitutions to unify the nation through elaborate ceremonies and dissemination of the document. CHAMBERS, supra note 91 , at 181 ("The elaborate ceremonies that had earlier reinforced allegiance to the monarch served after independence to legitimate the constitution."). Early constitutions were proclaimed by criers in the main plazas of towns so that the crowd could learn that they (or more accurately, some of them) would now be citizens with new rights. Id. Newspapers published the constitutions as well so that they could be read and discussed by the masses. Id. The Creoles spread the news about new constitutions and used them to inform the masses about the liberty and equality central to their vision for the new republic. In this way, constitutions contributed to the creation of the Peruvian nation.

138. Although I argue that constitution-making processes often exist alongside and facilitate nation-making, this article will focus on the actual texts of constitutions rather than the constitution-making process. This focus is informed by the history of constitution-making in Peru, which for the most part has been non-democratic.

139. Sinesio López Jiménez documents the tension faced by Peruvian political elites after independence. He contends that initially they considered indigenous peoples worthy of inclusion in the nation. SINESIO LÓPEZ JIMÉNEZ, CIUDADANOS REALES E IMAGINARIOS: Concepciones, DesarRollo y MaPas de la CiUdadanía EN El Perú 215 (1997) ("En un primer momento, los criollos y mestizos que conquistaron la independencia y que aún sentían los rescoldos dea la guerra decidieron que los indios era 'nuestros compatriotas y hermanos' y que como tales formaban parte de la nación peruana."). He notes that this moment, however, soon passed. Id. 
to provide any details about how Indians would be included in the new republic. The letter expressed concern for the Indians but did not extend representation to them. Throughout the early constitutions, Creoles responded to the 1822 letter's indeterminacy by struggling with their own desires to include Indians symbolically in the nation but exclude them from any meaningful participation in the political community. ${ }^{140}$

The first Peruvian constitution, written in 1823, reflected the tension in the 1822 letter by reinforcing the indeterminate place of Indians in the political community. ${ }^{141}$ It serves as a good template to compare to the 1822 letter and other nineteenth century Peruvian constitutions because many of its articles are similar to those in later constitutions and the differences between constitutional articles can be easily noted.

The 1823 Constitution demonstrates how Creoles continued to be torn between their ideals of equality and their fears of Indian insurgency. They dealt with this tension by distinguishing between Peruvian nationality and citizenship. The 1823 Constitution emphasized Peruvian nationalism by closely linking it to Peruvian sovereignty, which was characterized as residing in the nation. ${ }^{142}$ It defined the nation broadly by extending Peruvian "nationality" to anyone born in Peru to a mother or father who was Peruvian and to those who were naturalized as Peruvian. ${ }^{143}$ The responsibility of the nation was to protect individual rights, ${ }^{144}$ but these rights were guaranteed only to citizens and not to nationals. Citizenship was a more limited and restricted class than nationality. ${ }^{145}$ To qualify for citizenship, an individual had to be Peruvian, married or over 25 years of age, literate, and either to have a

140. Creole fears of Indian insurrection were key to the hesitancy expressed in these early constitutional documents.

141. Prior to the promulgation of the 1823 Constitution, the constitutional congress produced an interim document called "Bases de la Constitución Política de la República Peruana" almost a year earlier in December 1822. This earlier document asserts the independence of Peru from the Spanish monarchy and sketches the bare outlines of a constitutional structure for the new state. Antecedentes, Bases de la Constitución Política de la República Peruana (Dec. 16, 1822), at http://www.constperu.cjb.net (last visited Oct. 24, 2005).

142. La Constitución Política de la República Peruana, Sancionada por el Primer Congreso Constituyente el 12 de Noviembre 1823, art. 3, at http://www.congreso.gob.pe/ntley/imagenes/ constitu/cons1823.pdf (last visited Oct. 10, 2005) ("La soberanía reside esencialmente en la Nación").

143. Id. at art. 10 .

144. Id. at arts. 4-5.

145. THURNER, supra note 60 , at 24 (explaining that the term used in the constitution for a national, "peruano," referred to an Indian commoner rather than a citizen). 
profession or to own property. ${ }^{146}$ Citizenship could be suspended for criminal prosecution, scandalous behavior, or lack of employment. ${ }^{147}$

This definition of citizenship separated the Creole republic from its colonial past by negating the dualism of the Spanish Monarchy and by allowing any individual who could meet these requirements - regardless of race or ethnicity - to be a citizen. It further rejected the Spanish model by extending the same rights to all citizens equally. ${ }^{148}$ While it rescinded the dualism of Spanish rule, it created its own social stratifications based on the new categories of class, literacy, and age (which often served as proxies for race). Through this new system of social stratification, the Constitution created a civic model of liberal nationhood based on equality among citizens but limited these rights to responsible individuals who could meet the strict criteria for citizenship..$^{149}$

The Constitution retained the 1822 letter's ambiguous position towards Indians by formally but unrealistically providing them with the opportunity to qualify for citizenship. While Indians could technically be part of the "nation" by meeting the qualifications for nationality and were considered Peruvian, most had no more participation in the new republic than they had had in the previous Spanish Monarchy because they could not meet the requirements for citizenship. ${ }^{150}$ Instead Indians lost any special status or collective rights granted to them by the Spanish viceroyalty for the opportunity - as remote as it was - to join the new egalitarian Peruvian republic as individuals. ${ }^{151}$ The reality that few Indians would qualify for citizenship demonstrates how Creoles

146. La Constitución Política de la República Peruana, Sancionada por el Primer Congreso Constituyente el 12 de Noviembre 1823, supra note 142, at art. 17.

147. ChAMBERS, supra note 91 , at 190.

148. La Constitución Política de la República Peruana, Sancionada por el Primer Congreso Constituyente el 12 de Noviembre 1823, supra note 142, at art. 23, art. 193, § 9; THURNER, supra note 60, at 16-17 ("[T] he Creole citizenmaking project which renamed 'Indians' as 'Peruvians' logically implied the negation or displacement of the separate derechos, or colonial 'privileges,' and status derived from membership in the colonial Indian republic, in favor of the unitary civic model of liberal nationhood under the Peruvian Republic.").

149. CHAMBERS, supra note 91 , at 190.

150. Thurner presents a compelling story of how Indians viewed the new Peruvian republic and participated in their own ways. THURNER, supra note 60 . While I agree with his analysis, my focus here is on the place (or lack thereof) that the Creoles envisioned for Indians.

151. The 1823 Constitution foreshadowed the Indians' loss of the jurisdictional and communal land rights they had under Spanish rule. In 1824, Indian lands were parceled into individual private property and a year later, traditional Indian authorities ceased to be officially recognized by the government. Id . at $24-25$. While disempowering Indian communities, the new republic sought to exert direct jurisdiction over them. $I d$. at 24 . 
attempted to reconcile their liberal aspirations with their fears of Indian revolt and shows their anxiety over the prospect of creating a nation truly inclusive of Indians. Rather than resolving the tension in the 1822 letter, the 1823 Constitution recreated it by distinguishing between citizens with rights and nationals without rights.

The tension that surfaced in 1822 letter and 1823 Constitution would persist in later nineteenth century constitutions. New responses to the tension were crafted through changes in the citizenship provisions in the 1826 and 1828 Constitutions. These alterations indicate that the constitutional discourse on inclusion and exclusion continued. ${ }^{152}$ While the changes reflect new attempts by the Creoles to respond to the initial tension in the 1822 letter, they did more to reinforce the indeterminate constitutional status of indigenous peoples than to resolve it. The 1826 Constitution adopted almost the same language as the 1823 Constitution, ${ }^{153}$ but defined the nation as inclusive of all Peruvians. ${ }^{154}$ It retained the same criteria for citizenship, ${ }^{155}$ but included a new article, Article 16, which expanded citizenship to include the citizens of the Spanish American nations prior to the revolution. ${ }^{156}$ Thus, the 1826 Constitution merely reiterated the tension in the 1822 letter and 1823 Constitution.

152. The 1826 Constitution is the only Peruvian constitution not to have been approved by either a constitutional congress or constitutional assembly. Domingo García Belaunde, La Nueva Constitución del Perú: Poder Judicial y Garantías Constitucionales, in DESAFIOS CONSTITUTIONALES COMTEMPORANEOS 35 (César Landa \& Julio Faúndez eds., 1996). The 1826 Constitution asserts the nation's independence, Constitución Política Para la República Peruana 1826, art. 2, at http://www.congreso.gob.pe/ntley/imagenes/constitu/cons1826.pdf(last visited Oct. 10, 2005) ("El Perú es, y será para siempre, independiente de toda dominación extranjera"), explains that sovereignty emanates from the people, $i d$. at art. 8 ("La soberanía emana del pueblo"), and ensures equality under the law for all citizens (although slightly less emphatically than the earlier 1823 constitution), id. at art. 142 ("La libertad civil, la seguridad individual, la propiedad y la igualdad ante la ley, se garantizan a los ciudadanos por la Constitución.").

153. Id. at art. 11.

154. Id. at art. 1 ("La Nación Peruana es la reunión de todos los peruanos."). In contrast the 1823 Constitution defined the Peruvian Nation as a union of the provinces. La Constitución Política de la República Peruana, Sancionada por el Primer Congreso Constituyente el 12 de Noviembre 1823, supra note 142, at art. 1.

155. Constitución Política Para la República Peruana 1826, art. 14, at http://www.congreso. gob.pe/ntley/imagenes/constitu/cons1826.pdf(last visited Oct. 10, 2005) ("Para ser ciudadano es necesario: 1.- Ser peruano. 2.- Ser casado, o mayor de veinticinco años. 3.- Saber leer y escritir. 4.- algún empleo o industria; o profesar alguna ciencia o arte, sin sujeción a otro en clase de sirviente doméstico.").

156. Id. at art. 16 ("Los ciudadanos de las naciones de América antes española, gozarán de los derechos de ciudadanía el Perú, según los tratados que se celebren con ellas.”). 
The 1828 Constitution leaned towards a more inclusive approach to citizenship and nationality. The 1828 Constitution closed the gap between citizenship and nationality by ceasing to define the nation in terms of who was a Peruvian ${ }^{157}$ and by expanding Peruvian citizenship through the removal of the literacy, age, and property or profession requirements. ${ }^{158}$ Simultaneously, it expressly limited citizenship to men, and retained all of the earlier grounds for suspension and revocation of citizenship. ${ }^{159}$ For the first time, Peru removed limitations on citizenship, and male Indians, at least formally under the Constitution, could be Peruvian citizens. This shift in the definition of citizenship indicates that discussions and negotiations over who belonged to the citizenry and within the constitutional community continued.

For a few years, the constitutional definitions of citizenship and nationality gained some stability. The broad definition of citizenship in the 1828 Constitution survived constitutional changes in 1834. The new 1834 Constitution abandoned the earlier emphasis on nationalism, independence, and equality under the law by removing its earlier rhetoric defining and constituting the nation. ${ }^{160}$ Aside from defining the citizenry, it barely mentioned issues of citizenship and nationality. It simply retained the restrictions on citizenship established in the 1823 Constitution.

Early Peruvian constitutions suggest that Creoles struggled throughout the first decade after independence to respond to the tension in the 1822 letter and to reconcile their liberal democratic aspirations with their fears of Indian insurrections. Throughout the decade, their continual attempts to address this tension regularly changed with constitutional definitions of nationals and citizens. This constant change in definitions solidified a constitutional dialogue ambivalent about the place of Indians in the new republic started by the 1822

157. The 1828 Constitution continued to assert the independence of the Peruvian nation, Constitución Política de la República Peruana 1828, art. 2, at http://www.congreso.gob.pe/ ntley/imagenes/constitu/cons1828.pdf(last visited Oct. 10, 2005) ("La Nación Peruana es para siempre libre e independiente de toda potencia extranjera. No será jamás patrimonio de persona o familia alguna; ni admitirá con otro Estado unión o federación que se oponga a su independencia."), to define the nation as composed of its citizens, id. at art. 1 ("La Nación Peruana es la asociación política de todos los ciudadanos del Perú."), and to protect equality under the law. Id. at art. 149 ("La Constitución garantiza la libertad civil, la seguridad individual, la igualdad ante la ley, y la propiedad de los ciudadanos en la forma que sigue."), id. at art. 157 ("Todos los peruanos son iguales ante la ley, ya premie, ya castigue.").

158. Id. at art. 4.

159. Id. at arts. 5-6.

160. Constitución Política de la República Peruana 1834, at http://www.congreso.gob.pe/ ntley/imagenes/constitu/cons1834.pdf (last visited Oct. 10, 2005). 
letter. By the mid-1830s, the debate stabilized temporarily as Creole constitutionalism limited the place and participation of Indians within the Peruvian nation by enacting stringent criteria for citizenship. This strategy of exclusion through citizenship allowed Creole constitution-makers implicitly to exclude Indians while retaining an appearance of equality among men.

A crisis in Peruvian constitutionalism emerged in 1836 and the tension in the 1822 letter emerged as central to it. Creole nationalists faced a new threat to their vision of an exclusive Republican Peru with the arrival of Bolivian Marshall Andres Santa Cruz, and his dream of a unified Peruvian-Bolivian Confederation. ${ }^{161}$ Santa Cruz's project reopened the debate over the definition of the Peruvian political community by suggesting an alternative vision of the nation based on a political and economic alliance between Bolivia and Peru. ${ }^{162}$ His vision directly challenged the constitutional project being developed by Creole elites. His adversaries used the opportunity to solidify their own conception of the nation as exclusive of Indian citizenship. ${ }^{163}$ They exploited the tension between indigenous peoples and Creoles identified in the 1822 letter by characterizing Santa Cruz negatively as a foreigner and an Indian rather than a Peruvian. Using such rhetoric, Creole elites defeated his dream of a unified Peruvian-Bolivian Confederation. ${ }^{164}$

161. Cecilia Mendez G., Incas Si, Indios No: Notes on Peruvian Creole Nationalism and Its Contemporary Crisis, 28 J. LATIN AM. STUDIES 197, 205 (1996).

162. Santa Cruz did temporarily succeed in creating a Peruvian-Bolivian Confederation. The Confederation combined three separate states: Northern Peru, Southern Peru, and Bolivia through an economic alliance in October 1836. A fundamental law promulgated in 1837 supranationally governed the confederation and defined citizenship as common among the three. See La Ley Fundamental de la Confederación Perú-Boliviana, at http://www.congreso.gob.pe/ ntley/Imagenes/Constitu/Lcpb1837.pdf (last visited Oct. 10, 2005). Each individual state was also reportedly "given" a constitution by Santa Cruz. Lane Carter Kendall, Andres Santa Cruz and the Peru-Bolivian Confederation, 16 HISP. AM. HIST. REV. 29, 40-41 (1936). Generally, however, the split of Peru into two states undermined the larger Peruvian national project and subjugated Peru to Bolivia. Mendez, supra note 161, at 205.

163. In fact, adversaries to the Confederation would later call their eventual victory over Santa Cruz a second independence. Id. at 213.

164. Id. The characterization of Santa Cruz was based more on his family ties through an Aymara mother than a reflection of his actual policies towards Indians. He was better at winning political support from indigenous sectors than his Creole detractors but was not necessarily any more inclusive of them. $I d$. at 215 . In fact, the fundamental law that Santa Cruz devised to govern the Bolivian-Peruvian confederation did not provide any more extensive citizenship provisions than the early Peruvian constitutions. See La Ley Fundamental de la Confederación Perú-Boliviana, art. 4, at http://www.congreso.gob.pe/ntley/Imagenes/Constitu/ Lcpb1837.pdf (last visited Oct. 10, 2005). 
After the fall of the Confederation, Creole nationalists worked hard to restore the constitutional order they had previously started to create. ${ }^{165}$ Once again, they faced the dilemma of Indian inclusion. Though they espoused noble ideals of liberty, equality, and liberal rights, the Creole nationalists largely used anti-Indian rhetoric in their campaign to defeat Santa Cruz. Peruvian constitutions continued to reflect the tension between equality and indigenous exclusion. ${ }^{166}$ The 1839 Constitution returned to the language of the 1828 Constitution by defining the nation as the political association of Peruvians. ${ }^{167}$ At the same time, it vastly changed how citizenship was defined by creating a two-tiered system of citizenship similar to the distinction between nationality and citizenship in earlier constitutions. First, it used early definitions of nationality to define citizens as males naturalized, born in Peru, or having a Peruvian parent. ${ }^{168}$ Then it divided citizenship into subclasses by reviving some of the old status requirements for citizenship embodied in earlier constitutions. Those who would be able to vote and participate fully in the polity had to meet age, marriage, literacy, property ownership, and employment requirements. ${ }^{169}$ If an individual could not meet these requirements, he would not be able to participate. This distinction, much like those between citizens and nationals in earlier constitutions, excluded many Indians.

The 1839 Constitution challenged the formal inclusion but actual exclusion of indigenous peoples by providing for a temporary exception to the literacy requirement for Indians in regions where there were no primary schools. ${ }^{170}$ Although this literacy exemption was to expire a few years later in 1844, it reflects continued divisions within Creole nationalism about the place of

165. Mendez, supra note 161 , at 215 ("The process of restructuring the Peruvian state following the Confederation's defeat was called a 'restoration' in its day.").

166. The post 1839 consolidation led to what is often considered the paradox of Creole nationalism, namely that the creoles built a nation by rejecting the Indians who composed a majority of the person living in it. $I d$. at 219.

167. Constitución Política de la República Peruana 1839 art. 1, at http://www.congreso.gob. pe/ntley/imagenes/constitu/cons1839.pdf (last visited Oct. 10, 2005) ("La Nación Peruana es la asociación política de todos los peruanos."). It also reinserted the earlier assertions of Peruvian independence. Id. at art. 2 ("La Nación Peruana es libre e independiente: no puede ser patrimonio de ninguna persona ni familia, ni hacer con otro Estado pacto alguno, que se oponga a su independencia y unidad.").

168. Id. at arts. 4-6.

169. Id. at art. 8 .

170. Id. at art. $8 \S 2$ ("Saber leer y escribir, excepto los indígenas y mestizos, hasta el año de 1844, en las poblaciones donde no hubiere escuelas de instrucción primaria."); see also CHAMBERS, supra note 91, at 223 ("'II]n the early republic, literacy requirements were waived for indigenous and mestizo citizens.”). 
Indians in the new Republic. Creoles enacted a constitution formally extending the vote to some Indians just after using a racially exclusive definition of the nation to defeat Santa Cruz. ${ }^{171}$ Despite "official" and formal inclusion in the 1839 Constitution, few doubt that most Indians continued to be excluded from participation in Peruvian politics. ${ }^{172}$

The literacy exemption allowing illiterate Indians to vote was a short-lived experiment that would not resolve the question of where Indians fit within the Peruvian constitutional structure. The literacy exemption was removed in 1856 and not reintroduced even though other restrictions on citizenship remained intact. ${ }^{173}$ The literacy requirements for citizenship vanished from the constitution entirely in 1867 , but the other restrictions did not. ${ }^{174}$ The loss of the literacy requirement did not ensure Indian participation as they still had to meet the other requirements for citizenship. Further while restrictions on citizenship eased, new statutory qualifications for the franchise were enacted

171. Mendez, supra note 161, at 213.

172. See, e.g., BARIÉ, supra note 9, at 474 ("Sin embargo, pese a todos estos vaivenes politicos e ideológicos, del analisis de las constituciones republicanas del siglo XIX se desprende una tendencia prácticamente inmutable: la exclusíon sistemática de los indígenas del ejercicio ciudadano.").

173. Constitución Política de la República Peruana 1856 art. 37, at http://www.congreso. gob.pe/ntley/imagenes/constitu/cons1856.pdf(last visited Oct. 10, 2005) ("El sufragio popular es directo: lo ejercen los ciudadanos que saben leer y escribir, o son jefes de taller, o tienen una propiedad raíz, o se han retirado, conforme a la ley, después de haber servido en el Ejército o Armada.").

The 1860 Constitution also reiterated these citizenship restrictions. Constitución Política de la República Peruana 1860, art. 38, at http://www.congreso.gob.pe/ntley/imagenes/constitu/ cons1860.pdf (last visited Oct. 10, 2005). Both of these constitutions retained the strong language of a unified nationalism expressed in the 1839 Constitution and the emphasis on individual rights expressed in earlier nineteenth century constitutions. Constitución Política de la República Peruana 1856, art. 1, at http://www.congreso.gob.pe/ntley/imagenes/constitu/cons 1856.pdf (last visited Oct. 10, 2005) ("La Nación Peruana es la asociación política de todos los peruanos"); id. at art. 31 ("Las leyes protegen y obligan igualmente a todos: podrán establecerse leyes especiales porque lo requiera la naturaleza de los objetos pero no por solo la diferencia de personas."); Constitución Política de la República Peruana 1860, art. 1, at http://www. congreso.gob.pe/debate_constitucional.htm (visited Feb. 7, 2004) ("La Nación Peruana es la asociación política de todos los peruanos"); $i d$. at art. 32 (same as 1856 Const., art. 31)

174. Constitución Política de la República Peruana 1867, art. 39, at http://www.congreso. gob.pe/ntley/imagenes/constitu/cons1867.pdf (last visited Oct. 10, 2005) ("El sufragio popular es directo: gozan de este derecho todos los ciudadanos en ejercicio."). It also de-emphasized nationalism. Like all the constitutions of the nineteenth century, it protected individual rights and equality under the law. Id. at art. 30 . 
and applied to citizens. ${ }^{175}$ Thus, even Indians who could become citizens could not participate in the political community.

Peru's early constitutions indicate that the tension identified in the 1822 letter remained unresolved throughout the nineteenth century. Creoles during the nineteenth century used constitutional provisions defining citizenship and nationality to address whether and how Indians fit into the new republic. They wrote constitutions, which conveyed the ideal of a unified nation of all Peruvians, but divided nationality and citizenship. Nationality with its few privileges was extended to many while citizenship with its many privileges was limited to very few. While Creoles used these provisions to craft several responses to the tension in the 1822 letter, none of their attempts resolved it.

The shifts in the definition of citizenship in these constitutions indicate that the tensions in the 1822 letter continued to pervade constitutional politics. Uncertainty remained about how to treat Indians and whether to include them constitutionally in the nation by extending citizenship to them. Each constitution responded to the tension in its own way and all expressed ambivalence about the inclusion of Indians in the Peruvian political community. Although these constitutions left open the possibility of Indian citizenship at least for some, they ignored the economic, social, and educational discrimination that pervaded the daily lives of Indians and prevented them from attaining citizenship. These constitutions provided citizenship and full participation to a limited few, ambiguity towards some, and exclusion for the vast majority.

Ultimately the rise of the Aristocratic Republic at the end of the century solidified an anti-Indian Creole nationalism in Peru. But this would occur only after decades of varied attempts to address the tension in the 1822 letter. The Aristocratic Republic would exclude the majority of the population from political participation and be referred to later as 'a republic without citizens. ${ }^{176}$ Few doubt that for the majority of the nineteenth century, Indians remained problematic for Creole Peru. Indians were largely unimagined and outside of

175. Indians were also marginalized in the politics of the emerging party system. See generally Julio Cotler, Political Parties and the Problems of Democratic Consolidation in Peru 335, in BUILDING DEMOCRATIC InSTITUTIONS: PARTY SYSTEMS IN LATIN AMERICA (Scott Mainwaring \& Timothy Scully eds., 1995). For more on the historical exclusion of indigenous peoples in Peru, see Maria Isabel Remy, The Indigenous Population and Construction of Democracy in Peru 107, in INDIGENOUS PEOPLES AND DEMOCRACY IN LATIN AMERICA (Donna Lee Van Cott ed., 1994).

176. López, supra note 106, at 217; see also WALKER, supra note 55, at 223 (noting the liberal assault on Indian communities at the end of the nineteenth century). 
the nation created by political elites and the constitutional order simply did not know how to treat them. ${ }^{177}$

\section{The More Things Change, the More They Stay the Same: Indigenous Peoples in Twentieth Century Peruvian Constitutional Politics}

The twentieth century inherited many of the identity problems of the nineteenth century and these issues continued to shape constitutional politics. ${ }^{178}$ The challenges to nationalism, foreshadowed by the 1822 letter, would increase in complexity during the twentieth century as identities and identity politics changed and diversified. ${ }^{179}$ Early in the century, the question of how to include indigenous peoples faced new challenges, as indigenous peoples demanded recognition of their collective rights. Thus, the tension took on a new dimension about whether to define indigenous peoples as individual citizens or to recognize their rights as autonomous groups. This new dimension reshaped the contours of the old debate and introduced a new response to the question of indigenous inclusion. By the end of the twentieth century, constitutionmakers had resolved that indigenous peoples belonged to the Peruvian constitutional community and the focus shifted to the question of how indigenous peoples should be included in that community. Despite these changes, the ambivalence towards indigenous peoples in the 1822 letter would neither be abandoned nor fully resolved. Instead it would continue to frame a constitutional order uncertain about the relationship between Creoles and Indians.

The emergence of indigenous movements and their demands for land challenged Creole nationalism and prompted Peruvian constitution-makers to revisit the question of the place of indigenous peoples in the constitution several times during the twentieth century. ${ }^{180}$ The 1920 Constitution responded

177. Mendez, supra note 161, at 221-22; THURNER, supra note 60, at 12 ("The contemporary Indian remained unimagined"); Jean Piel, The Place of the Peasantry in the National Live of Peru in the Nineteenth Century, PAST \& PRESENT, Feb. 1970, at 108 (issue number 46); BARIÉ, supra note 9 , at 474.

178. López, supra note 106 , at 219.

179. For instance, agrarian reform policies of the 1960 s and 1970 s would define rural identity by class rather than ethnicity. Later indigenous movements would challenge class identity as predominant. Further, urban migration altered identity entirely. For an in-depth discussion of these changes, see López, supra note 106, at 219-29.

180. Raquel Yrigoyen Fajardo, Peru: Pluralist Constitution, Monist Judiciary - A PostReform Assessment, in MULTICULTURALISM IN LATIN AMERICA: INDIGENOUS RightS, DIVERSITY AND DEMOCRACY 160 (Rachel Sieder ed., 2002). For more information on the indigenist revival in the early nineteenth century, see Marisol de la Cadena, The Political 
to these new movements by recognizing indigenous communities and their inalienable rights to communal lands. ${ }^{181}$ The constitutional recognition of communal indigenous land rights did not resolve the tension in the 1822 letter but introduced a new element to the debate. While previously political elites had envisioned an individual-based model of inclusion through citizenship and the extension of individual rights, they now faced questions of collective rights. Despite a century old aspiration of individual equality, elites continued to deny indigenous peoples the franchise while extending collective rights to them. ${ }^{182}$ Thus, the constitutional tension identified in the 1822 letter shifted in 1920 from one solely concerned with individual rights to one open to collective indigenous rights.

This shift added a twist to the tension by creating a new question about whether indigenous peoples should be treated as individuals or groups. The recognition of collective indigenous rights appeared counter to ideals of individual equality. The 1920 Constitution revived the language of a unified, national state used in the 1839,1856 , and 1860 Constitutions. ${ }^{183}$ It also reiterated the importance of equality under the law and the rights of the individual. ${ }^{184}$ The privileging of the unified nation and the rights of the individual existed in tension with the new acknowledgement of collective rights specific to indigenous peoples, which were based on the recognition of peoples

Tensions of Representations and Misrepresentations: Intellectuals and Mestizas in Cuzco (19191990), 2 J. LATIN AM. ANTHROPOLOGY 112-47 (1996); Marisol de la Cadena, De Raza a Clase: La Insurgencia Intelectual Provinciana en el Perú (1910-1970), in LOS SENDEROS INSÓLITOS DEL PERÚ, 1980-1995 (Steven J. Stern ed., 1998).

181. Constitución Política de la República Peruana 1920, art. 41 ("Los bienes de propiedad del Estado, de instituciones públicas y de comunidades de indígenas son imprescriptibles y sólo podrán transferirse mediante título público, en los casos y en la forma que establezca la ley"), art. 58 ("El Estado protegerá a la raza indígena y dictará leyes especiales para su desarrollo y cultura en armonía con sus necesidades. La Nación reconoce la existencia legal de las comunidades de indígenas y la ley declarará los derechos que les correspondan"), at http:// www.congreso.gob.pe/ntley/imagenes/constitu/cons1920.pdf (last visited Oct. 10, 2005).

182. López, supra note 106, at 234 ("A partir de los años veinte las nuevas elites modernizantes vinculadas al leguiismo, los nuevos sectores intelectuales y los movimientos indigenistas contribuyeron a que el Estado se declarara protector de la raza indígena, impulsara el reconocimiento formal de su cultura, reconociera su organización comunal, pero la excluyera de la participación política al exigir a los votantes el status de contribuyentes, la condición de alfabetos y hombres mayors de 21 años.").

183. Constitución Política de la República Peruana 1920, art. 1, at http://www.congreso.gob. pe/ntley/imagenes/constitu/cons1920.pdf (last visited Oct. 10, 2005) ("La Nación Peruana es la asociación política de todos los peruanos").

184. Id. at art. $17 \&$ Titulo III. 
or groups rather than equality among individuals. ${ }^{185}$ This development altered the debate in Peruvian society about the proper place of indigenous peoples by raising the issue of whether to recognize collective or individual rights or both. ${ }^{186}$ For the first time constitution-makers appeared to recognize that indigenous peoples belonged to the Peruvian political community, but how to include them was far from clear and their constitutionally ambiguous status continued.

The 1933 Constitution continued the indeterminacy. The constitution was rewritten in 1933 after the fall of the dictator Leguía to signify a new legal regime but little changed in the constitution. Instead the 1933 Constitution basically copied the 1920 Constitution. ${ }^{187}$ By reiterating many of the same provisions enacted in the 1920 Constitution, the 1933 Constitution left intact the conflict between equal treatment of individuals under the law and the recognition of indigenous rights.

Questions of the constitutional status of indigenous peoples gained new importance in the years between the 1933 and 1979 constitutions. The place

185. BARIÉ, supra note 9 , at 475.

186. See e.g., Will Kymlicka, Three Forms of Group-Differentiated Citizenship in Canada, in DEMOCRACY AND DIFFERENCE: CONTESTING THE BOUNDARIES OF THE POLITICAL 163 (Seyla Benhabib ed., 1996).

187. BARIÉ, supra note 9, at 477. It reiterated the emphasis on equality among individuals, Constitución Política de la República Peruana 1933, art. 23, at http://www.congreso.gob.pe/ ntley/imagenes/constitu/cons1933.pdf(last visited Oct. 10, 2005) ("La Constitución y las leyes protegen y obligan igualmente a todos los habitantes de la República. Podrán expedirse leyes especiales porque lo exija la naturaleza de las cosas, pero no por las diferencias de personas."), lowered the age of citizenship to eighteen years but kept the other restrictions on citizenship and voting, $i d$. at arts. 84-86, recognized the distinct legal status of indigenous communities, $i d$. at art. 207 ("Las comunidades indígenas tienen existencia legal y personería juridical."), and obligated the state to protect indigenous communal property rights, id. at art. 208 ("El Estado garantiza la integridad de la propiedad de las comunidades. La ley organizará el catastro correspondiente."); id. art. 209 ("La propiedad de las comunidades es imprescriptible en inenajenable, salvo el caso de expropiación por causa de utilidad pública, previa indemnización. Es, asimismo, inembargable"). In addition to these provisions, it attempted to deal with a tension in the 1920 document between indigenous communities and municipalities by addressing the powers of the municipalities vis-à-vis indigenous communities. Id. at art. 210 ("Los Concejos Municipales ni corporación o autoridad alguna intervendrán en la recaudación ni en la administración de las rentas y bienes de las comunidades."). The 1933 Constitution also somewhat undermined the communal property rights it recognized by allowing the state to procure excess indigenous lands. Id. at art. 211 ("El Estado procurará de preferencia adjudicar tierras a las comunidades de indígenas que no las tengan en cantidad suficiente para las necesidades de su población, y podrá expropiar, con tal propósito, las tierras de propiedad privada conforme a lo dispuesto en el párrafo segundo del artículo 29."). 
of indigenous peoples in the nation changed in 1974 with explicit discussions about how native Amazonians fit into the legal structure. ${ }^{188}$ Ultimately these discussions culminated in the enactment of the 1974 Law of Native Communities, which acknowledged the rights of Amazonian Indians to territorial and sub-soil rights and the legal rights of these communities to resolve their own internal disputes. ${ }^{189}$ An advance for Andean indigenous peoples also came in 1975 when Peru finally fulfilled the promise originally made in the 1822 letter and recognized their language, Quechua, as an official language. ${ }^{190}$

Constitutional negotiations in the late 1970s provided a space for resolving the question of how indigenous peoples were to be included in the constitutional order. The 1979 Constitution, however, retained many of the contradictions in earlier constitutions and reflected the tension between indigenous peoples and the state identified in the 1822 letter. President General Juan Velasco Alvarado advocated agrarian reforms that rejected indigenous peoples as a salient identity group and identified them as "campesinos" (peasants) rather than indigenous peoples. While this definitional change privileged class identities over other ones, the question of Amazonian indigenous groups had surfaced for the first time in the 1979 constitutional debates and their existence reiterated claims of indigenous communal identity. ${ }^{191}$ After much debate, a new chapter on indigenous peoples was added to the Constitution even though the emphasis on individual rights was retained. The inclusion of recognitions of both indigenous rights and individual rights reaffirmed the indeterminacy towards indigenous peoples that started with the 1822 letter. Constitution-makers were still unsure as to whether to include indigenous peoples as individuals or communities, and the debate continued about how to include indigenous peoples and whether to recognize their claims to collective rights. ${ }^{192}$

188. Yrigoyen Fajardo, supra note 180 , at 161.

189. Id.

190. BARIÉ, supra note 9, at 478-79.

191. Indigenous social movements were also forming throughout the Andean region (mainly in neighboring Ecuador and Bolivia) at this time. See generally XAVIER AlBó, Los PUEBLOS INDIOS EN LA POLITICA (2002); Deborah Yashar, Democracy, Indigenous Movements, and the Postliberal Challenge in Latin America, 52 WORLd Politics 76 (1999); HenRI FAVRE, EL INDIGENISMO (1998).

192. Debate continues about the recognitions of indigenous rights incorporated in the 1979 Constitution and whether they increased or decreased the rights of indigenous peoples. Yrigoyen Fajardo asserts that the 1979 Constitution rejected the notion of legal pluralism and returned Peru to a state of legal monism. Yrigoyen Fajardo, supra note 180, at 162. Barié 
The 1979 Constitution illustrated the indeterminate place of indigenous peoples through its inconsistent treatment of indigenous peoples as equal citizens and semi-autonomous groups. In this way, it furthered the ambiguous constitutional narrative. It both reiterated and limited the recognitions of indigenous rights codified in the earlier 1920 and 1933 Constitutions and did not resolve the tension between the recognition of indigenous rights and equality before the law that first arose in the 1920 Constitution. ${ }^{193}$ The 1979 Constitution recognized the importance of indigenous languages, ${ }^{194}$ acknowledged the distinct status of indigenous communities, continued the restrictions on the sale of communal indigenous property, ${ }^{195}$ and expanded protections of indigenous culture. ${ }^{196}$ At the same time, it limited the ability of indigenous communities to resolve their own disputes and stated that these indigenous protections depended largely on their development and enforcement through statutes. ${ }^{197}$ The 1979 Constitution included a new provision on indigenous development, which was to be promoted by the state, ${ }^{198}$ but aside

contends that the 1979 Constitution greatly expanded indigenous rights. BARIÉ, supra note 9 , at 479-82. The two scholars also disagree on the effects of the 1993 Constitution. Barié argues that the 1993 Constitution greatly undermined the indigenous rights previously included in the 1979 Constitution, id. at 482-83, while Yrigoyen Fajardo claims that the 1993 Constitution moved Peru away from legal monism and towards legal pluralism for the first time, Yrigoyen Fajardo, supra note 180, at 167-71.

193. Constitución Política de la República Peruana 1979, art. 2 2, at http://www.congreso. gob.pe/ntley/imagenes/constitu/cons1979.pdf (last visited Oct. 10, 2005) ("A la igualdad ante la ley, sin discriminación alguna por razón de sexo, raza, religión, opinión e idioma.").

194. Id. at art. 35 ("El Estado promueve el estudio y conocimiento de las lenguas aborígenes. Garantiza el derecho de las comunidades quechuas, aymara y demás comunidades nativas a recibir educación primaria también en su propio idioma o lengua.").

195. Id. at art. 163 ("Las tierras de las Comunidades Campesinas y Nativas son inembargables e imprescriptibles. También son inalienables, salvo ley fundada en el interés de la Comunidad, y solicitada por una mayoría de los dos tercios de los miembros calificados de esta, o en caso de expropiación por necesidad y utilidad publicas. En ambos casos con pago previo en dinero. Queda prohibido el acaparamiento de tierras dentro de la Comunidad.").

196. Id. at art. 34 ("El Estado preserva y estimula las manifestaciones de las culturas nativas, así como las peculiares y genuinas del folklore nacional, el arte popular y la artesanía").

197. Id. at art. 161 ("La Comunidades Campesinas y Nativas tienen existencia legal y personería jurídica. Son autónomas en su organización, trabajo comunal y uso de la tierra, así como en lo económico y administrativo dentro del marco que la ley establece. El Estado respeta y protege las tradiciones de las Comunidades Campesinas y Nativas. Propicia las superación cultural de sus integrantes.").

198. Constitución Política de la República Peruana 1979, art. 162, at http://www.congreso. gob.pe/ntley/imagenes/constitu/cons1979.pdf(last visited Oct. 10, 2005) ("El Estado promueve el desarrollo integral de las Comunidades Campesinas y Nativas. Fomentan las empresas comunales y cooperatives."). 
from making indigenous lands inalienable, it did not protect indigenous communities from the possible harms of development. ${ }^{199}$

These provisions existed in awkward juxtaposition to a constitutional focus on equality before the law that specifically targeted certain kinds of discrimination as illegal. The Constitution listed several suspect categories of discrimination, including sex, race, religion, opinions, and beliefs. ${ }^{200}$ The specific listing of race as a proscribed category of discrimination created an even starker tension between the state's desire for equality under the law and its protections of indigenous rights. If the state actually desired the end of all racial discrimination, whether benign or invidious, then the anti-discrimination provisions could negate indigenous rights if they were perceived as race based. ${ }^{201}$

The indeterminate position of indigenous peoples also emerged in the 1979 Constitution's dual emphasis on national political integration and indigenous autonomy. The Constitution removed literacy requirements from voter eligibility and fully enfranchised indigenous peoples..$^{202}$ The enfranchisement of indigenous peoples signaled a move towards the political integration of indigenous peoples into the Peruvian state. While full enfranchisement

199. Id.

200. $I d$.

201. I do not mean to suggest that the recognition of indigenous rights necessarily contradicts equality rights - only that it could. Peru's lack of attention to the potential conflict is what concerns me here. Peruvian constitutions provide no guidance on the relationship between equality and indigenous rights, leaving open the door for arguments that indigenous rights are racially based, and thus, unconstitutional. Consider, in contrast, Canada's constitutional recognition of Aboriginal rights. Canada recognizes Aboriginal rights as based upon a government-to-government relationship between Aboriginal nations and the Canadian government initiated by the Royal Proclamation of 1763 . See generally supra note 49 . This government-to-government relationship is political, not racial, and thus, not in conflict with Canada's equality protections. Id. While not constitutionally based, the United States has made similar arguments in regard to its relationship with Indian tribes. Morton v. Mancari, 417 U.S. 535 (1974).

202. Constitución Política de la República Peruana 1979, art. 65, at http://www.congreso. gob.pe/ntley/imagenes/constitu/cons1979.pdf(last visited Oct. 10, 2005) ("Son ciudadanos los peruanos mayores de dieciocho años. Para el ejercicio de la ciudadanía se requiere estar inscrito en el Registro Electoral. Tienen derecho a votar todos los ciudadanos que están en el goce de su capacidad civil. El voto es personal, igual, libre, secreto y obligatorio hasta los setenta años. Es facultativo después de esta edad. En las elecciones pluripersonales, hay representación proporcional, conforme al sistema que establece la ley."); BARIÉ, supra note 9, at 480 ("Los derechos políticos de los indígenas, antes que nada, se plasman en la inclusión (indirecta) de esta población al electorado común: a más de 150 años de la primera Constitución republicana, los analfabetos, finalmente adquieren el derecho a acudir a las urnas."). 
clarified that indigenous peoples belonged to the Peruvian political community and resolved some of the ambivalence in the constitutional order, it did not resolve how to include indigenous peoples but exacerbated the tension between indigenous autonomy and individual rights. To some extent, the granting of political inclusion through enfranchisement, the most fundamental of the liberal individual political rights, undermines arguments made by some indigenous groups for recognition of and respect for their own political autonomy separate from the Peruvian state. ${ }^{203}$ The tension between assimilation and autonomy was further evident in the 1979 Constitution as it continued to define Peru as a monocultural nation while extending protections of indigenous culture. ${ }^{204}$

These three constitutional acts - the protection of equality, the enfranchisement of indigenous peoples, and monocultural national definition, suggest that a policy of assimilation persisted despite the formal recognition of specific indigenous rights. ${ }^{205}$ The 1979 Constitution may have resolved the indeterminacy of whether indigenous peoples belonged to the political community by extending enfranchisement and full political rights to them but the debate over how to include them continued. The tension between the acknowledgement of a distinct place for indigenous peoples and integrationist/assimilationist aspirations indicates that the Peruvian national and constitutional project has not resolved the question of how to include indigenous peoples raised in the 1822 letter.

The 1993 Constitution reinforced the confusion about how to include indigenous peoples in the political community left by the 1979 Constitution. The Constitution was reformed in 1993 primarily to suit the political ambitions of President Alberto Fujimori. ${ }^{206}$ Much like in 1979, indigenous rights were on the agenda and included in the final document. The 1993 Constitution, like many of the other Peruvian constitutions, represents the hesitant "one step forward, two steps back" approach towards indigenous peoples apparent since

203. For more on this kind of tension, see Charles Taylor, The Politics of Recognition, in Multiculturalism EXAMINING the Politics OF RECOGNITION 25-74 (Amy Guttman ed., Princeton Univ. Press 1994); CHARLES TAYLOR, RECONCILING THE SOLICITUDES ESSAYS ON CANADIAN FEDERALISM AND NATIONALISM (1993); Will Kymlicka, supra note 186, at 153-70.

204. BARIÉ, supra note 9 , at 481.

205. After enactment of the 1979 Constitution, organizations published books to inform the Amazonian indigenous peoples about their rights. The books look like civics books for elementary schools. They appear to explain the constitutional recognitions of aboriginal rights to the natives and encourage their participation in elections. They demonstrate further aspirations for the inclusion of Indigenous peoples into a national political community.

206. Maria McFarland Sanchez-Moreno, Note: When a "Constitution" Is a Constitution: Focus on Peru, 33 N.Y.U. J. INT'L L. \& POL. 561, 563-64 (2001). 
the 1822 letter in Peru. ${ }^{207}$ On one hand, the 1993 Constitution repeats the language of equality before the law present in its 1979 predecessor $^{208}$ and unequivocally describes the Peruvian state as singular and indivisible. ${ }^{209}$ Thus, it presents the nation as unified and monocultural with inclusion occurring through citizenship and equal rights. On the other hand, it simultaneously protects ethnic identity in general, ${ }^{210}$ recognizes indigenous languages as official languages in areas where they are dominant, ${ }^{211}$ confirms legal recognition and the inalienability of indigenous communal lands, ${ }^{212}$ and extends recognition of indigenous jurisdiction over community disputes. ${ }^{213}$ While these rights are not unlimited, they suggest inclusion through the recognition of separate indigenous communities. ${ }^{214}$

These contrary provisions and the limitations on the rights of indigenous groups indicate the state's continued uncertainty about how to include indigenous peoples in the constitutional political community. They suggest that the state is not prepared to abandon completely its long standing devotion to the integration or assimilation of indigenous peoples into the Peruvian political community. ${ }^{215}$ Instead, the position towards indigenous peoples within the Constitution remains unclear and vacillates much like in the original 1822 letter.

The debate over the place of indigenous groups and their rights under the constitution continues today with the reforms presented to the current Constitutional Commission, which was formed in 2001 by interim President

207. ROQUe RoldAN \& ANA MARIA CAMAYO, LEGISLACIÓN Y DERECHOS INDÍGENAS EN EL PERÚ 57 (1996).

208. Constitución Política de la República Peruana 1993, art. 2, § 2, at http://www.congreso. gob.pe/ntley/imagenes/constitu/cons1993.pdf(last visited Oct. 10,2005). By 1993, some of the language of indigenous rights almost appears to be boilerplate for Peruvian Constitutions and retained without much debate.

209. Id. at art. 43.

210. Id. at art. $2, \S 19$.

211. Id. at art. 48.

212. Id. at arts. 88-89.

213. Id. at art. 149 .

214. For instance, in protecting indigenous communal lands as inalienable, the 1993 Constitution also gives the state the right to claim abandoned lands, $i d$. at art. 88, and identifies the nation as the possessor of all natural resources, $i d$. at art. 66. Similarly, the right of indigenous communities to exercise their own jurisdictional authority in resolving disputes is limited because such judicial processes cannot violate fundamental human rights. $I d$. at art. 149.

215. BARIÉ, supra note 9, at 485 ("casi cien anos de la Independencia, el Estado no ha abandonado la idea de ser 'uno e indivisible' e insiste en una finalidad integracionista."). 
Valentin Paniagua to discuss potential reforms to the 1993 Constitution. ${ }^{216}$ The Commission, ${ }^{217}$ composed of Peru's finest jurists, politicians, and constitutional law scholars produced a report called the Anteproyecto on April 5, 2002. ${ }^{218}$ The Anteproyecto includes an entire chapter devoted to the rights of the Andean Pueblos, Amazonians, and Afro-Peruvian populations. ${ }^{219}$ Title Two Chapter Six contains proposals by the National Commission of Andean Pueblos and Amazonians, Congressman Luis Guerrero, and Congresswoman Martha Moyano. ${ }^{220}$ The most extensive proposal by the National Commission recommends vast recognitions of the rights of Andean and Amazonian indigenous peoples, including rights to land and minerals, bilingualism, cultural patrimony, autonomy, economic development, political participation, and the administration of justice. ${ }^{221}$. Additionally, it advocates the introduction of language ensuring the judicial enforcement of these rights. ${ }^{222}$ These proposals demonstrate the continued relevance of the debate over the place of indigenous peoples in the Peruvian constitutional polity and the persistent ambivalence about how to treat them. The question now is whether the latest round of constitutional reforms will finally answer the tough questions about how indigenous peoples should be included or if it will continue to leave these questions unresolved.

This short history lesson illustrates the legacy of the 1822 letter. The constitutions of Peru show how the tension in the 1822 letter started a longstanding debate within Peruvian constitutional politics about the relationship between the state and its indigenous peoples. This comparative analysis of Peruvian Constitutions indicates that the question of how to include

216. Carlos Lozada, Peru's Never-ending Quest for the Perfect Constitution, CHRISTIANSCI. MONITOR, Sept. 24, 2002, available at http://www.csmonitor.com/2002/0924/p07s01-woam. htm. Fujimori fled Peru for Japan due to allegations of systemic corruption. Id. Paniagua's actions follow the traditional Latin American pattern of constitutional change as part of regime change. Paniagua sought to rid Peru of the vestiges of the Fujimori regime. Id.

217. The full name of the commission is the Commission to Study the Bases for the Constitutional Reform of Peru, or El Comisión de Estudio de las Bases de la Reforma Constitutional del Perú.

218. Comisión de Constitución, Reglamento y Acusaciones Constitucionales, Congreso de la República, Anteproyecto de Ley de Reforma de la Constitución 58-62 (2002), available at http://www.congreso.gob.pe/comisiones/2002/debate_constitucional/anteproyecto.htm (last visited Oct. 10, 2005).

219. Title 2, Chapter 6 of the Anteproyecto is titled, "Of the Rights of the Andean Pueblos, Amazonians, and Afro-Pervian Populations." Id. at 58.

220. Id. at 58-62.

221. Id.

222. See supra note 1. 
indigenous peoples in the political community reemerged time and time again. Each new constitution responded to this tension as Peruvian constitutionmakers struggled to answer the questions of whether and how indigenous peoples are included in their political community.

The 1822 letter can be read against the nineteenth century constitutions to suggest that the community clearly did not include Indians, who despite their collective constitutional recognition in the 1920s would be excluded as illiterates from joining the Republic in any participatory manner until the 1970s. Such a reading, however, may obscure a more valuable point here about the ambiguities, tensions, and uncertainties that exist within the creation of imagined constitutional communities because it leaves out the recurrence of the question of inclusion and exclusion at that and later times. This comparison of the early constitutions indicates that the debate over who was part of the national community persisted throughout the nineteenth century and constitutional entitlements to the franchise and citizenship changed with each subsequent constitution. These continual constitutional changes suggest that the story is more complex and nuanced than a reading of the texts to exclude Indians indicates. A better reading of the nineteenth century constitutions highlights their struggles with indigenous inclusion and shows how they recreated the initial ambivalence towards indigenous peoples in the 1822 letter. In doing this, they reinforced and contributed to a constitutional order chronically indecisive about how to treat indigenous peoples.

The twentieth century constitutions differed in their approach to the question of indigenous inclusion. While they introduced and developed the idea of collective indigenous rights, they failed to resolve the constitutional order's ambivalence over how to include indigenous peoples. Peruvian constitutional documents responded to the tensions in the 1822 letter in different ways but all entered into the dialogue, addressed the underlying tension, and added to the constitutional debate it started.

While the 1822 letter has not received the same widespread acclaim as our Declaration of Independence, the Canadian Royal Proclamation, or New Zealand's Treaty of Waitangi, it can be used as diagnostic tool to identify and better understand a tension that was present at constitution-making and has remained unresolved today. Critical analysis of the letter shows that it identifies its main issue as the question of how to include indigenous peoples within the constitutional community. Comparison of the 1822 letter to later constitutional documents demonstrates that this question about the Peruvian political community has remained central to Peruvian constitutional politics and has historically framed persistent constitutional debates over who constitutes the Peruvian political community. An understanding of the 1822 letter 
facilitates a more complete picture of the creation and debate over the constitutional status of indigenous peoples. It suggests the early origin of the repeated discussions over citizenship, nationality, and collective rights in Peruvian constitutionalism. Without acknowledging the letter and the role it has played in the creation of constitutional meaning in Peru, we lose a sense of the deep anxiety and historical conflict over the definition of the Peruvian constitutional community.

Nearly two hundred years after production of the 1822 document, Peru continues to struggle with its relationship with indigenous peoples. The tension in the 1822 letter continues to be invoked in constitutional debates and discussions of the political community. In addition to identifying this tension, understanding the 1822 letter provides some insights into how the tension may be resolved. First, the 1822 letter suggests that this is not an easy tension to resolve. It presented more than one possible story about the community being created and it attempted, albeit inconsistently, to create a community by including Indians and appealing to them in the revolution against Spain. While it struggled with the place in the newly created nation of an "other" that it did not know how to define or include, it indicated that they could be included. It suggested that the question may be open to more than one creative solution. Second, the 1822 letter indicates the need to resolve the issue. It illustrates the longstanding duration of ethnic conflicts within a political community and suggests that if the issue is not taken seriously at this constitutional moment, it will persist.

\section{Conclusion}

Despite the vibrant fireworks displays and ticker tape parades of the Fourth of July, the status of pre-constitutional documents, including the beloved Declaration of Independence, remains in the dark. In the United States, at least we have reached the point of debating the legal force of the Declaration and other pre-constitutional documents. ${ }^{223}$ Pre-constitutional documents in other constitutional orders have not even had this much light shed on them. As precursors to final constitutions, pre-constitutional documents constitute a unique genre of constitutional documents and may provide key insights into the founding of the constitutional community. They deserve more attention than some of them have previously received and should be seriously considered by their respective constitutional orders. 
Pre-constitutional documents deserve to be the objects of critical discussion and analysis within contemporary constitutional orders because they help us to develop more comprehensive understandings of constitutionalism. While occasionally the tensions identified in pre-constitutional documents force the constitutional order to recognize their importance, as in the case of the Treaty of Waitangi in New Zealand or the Royal Proclamation in Canada, that is not always the case. Without critical analysis, the lessons contained in preconstitutional documents may be overlooked or lost. While not all preconstitutional documents highlight longstanding tensions within the constitutional policy, without critical analysis of these documents, we will not be able to determine which ones do.

The critical analysis of pre-constitutional documents often reveals the important role they play in contemporary constitutional politics. Preconstitutional documents may serve as diagnostic tools for identifying and better understanding constitutional tensions that remain unresolved to the present. The tensions identified by pre-constitutional documents are not forgotten or abandoned once a constitution is drafted. Rather these early tensions often reemerge in constitutional debates.

As this case study of the 1822 letter shows, the critical analysis of preconstitutional documents is key to understanding their importance to contemporary constitutional politics. The exploration of pre-constitutional documents unravels the historical layers of the constitutional order and the constitutionalism it has fostered by providing a window into the social construction of meaning in the constitution and the community it was designed to govern. Pre-constitutional documents provide background to later debates and illustrate their origin and continued importance in the constitutional dialogue.

By understanding pre-constitutional documents and their social context, we gain insights into how subsequent constitutional debates responded to these early constitutional tensions. Developing this understanding facilitates fuller comprehension of contemporary constitutional issues because it provides us with a lens through which to see the problem. The study of pre-constitutional documents enhances our understanding of our constitutional origins, increases the depth of our knowledge of our most salient constitutional debates, and encourages us to develop solutions to longstanding constitutional tensions. 